\title{
BMJ Open Prognostic models in acute pulmonary embolism: a systematic review and meta-analysis
}

\author{
Antoine Elias, ${ }^{1,2}$ Susan Mallett, ${ }^{3}$ Marie Daoud-Elias, ${ }^{1}$ Jean-Noël Poggi, ${ }^{1}$ \\ Mike Clarke ${ }^{4}$
}

To cite: Elias A, Mallett S, Daoud-Elias M, et al. Prognostic models in acute pulmonary embolism: a systematic review and meta-analysis. BMJ Open 2016;6:e010324. doi:10.1136/bmjopen-2015010324

- Prepublication history and additional material is available. To view please visit the journal (http://dx.doi.org/ 10.1136/bmjopen-2015010324).

Received 22 October 2015 Revised 18 March 2016 Accepted 22 March 2016

CrossMark

\footnotetext{
${ }^{1}$ Department of Vascular Medicine, Sainte Musse Hospital, Toulon La Seyne Hospital Centre, Toulon, France

${ }^{2}$ DPhil Programme in Evidence-Based Healthcare, University of Oxford, Oxford, UK

${ }^{3}$ Department of Primary Care Health Sciences, University of Oxford, Oxford, UK

${ }^{4}$ Northern Ireland Network for Trials Methodology Research, Queen's University Belfast, Belfast, UK
}

Correspondence to Dr Antoine Elias; antoine.elias@free.fr

\section{ABSTRACT}

Objective: To review the evidence for existing prognostic models in acute pulmonary embolism (PE) and determine how valid and useful they are for predicting patient outcomes.

Design: Systematic review and meta-analysis. Data sources: OVID MEDLINE and EMBASE, and The Cochrane Library from inception to July 2014, and sources of grey literature.

Eligibility criteria: Studies aiming at constructing, validating, updating or studying the impact of prognostic models to predict all-cause death, PE-related death or venous thromboembolic events up to a 3-month follow-up in patients with an acute symptomatic PE. Data extraction: Study characteristics and study quality using prognostic criteria. Studies were selected and data extracted by 2 reviewers.

Data analysis: Summary estimates $(95 \% \mathrm{Cl})$ for proportion of risk groups and event rates within risk groups, and accuracy.

Results: We included 71 studies (44 298 patients). Among them, 17 were model construction studies specific to PE prognosis. The most validated models were the PE Severity Index (PESI) and its simplified version (sPESI). The overall 30-day mortality rate was $2.3 \%(1.7 \%$ to $2.9 \%)$ in the low-risk group and $11.4 \%$ $(9.9 \%$ to $13.1 \%)$ in the high-risk group for PESI ( 9 studies), and $1.5 \%(0.9 \%$ to $2.5 \%)$ in the low-risk group and $10.7 \%(8.8 \%$ to $12.9 \%)$ in the high-risk group for SPESI (11 studies). PESI has proved clinically useful in an impact study. Shifting the cut-off or using novel and updated models specifically developed for normotensive PE improves the ability for identifying patients at lower risk for early death or adverse outcome $(0.5-1 \%)$ and those at higher risk (up to $20-29 \%$ of event rate).

Conclusions: We provide evidence-based information about the validity and utility of the existing prognostic models in acute PE that may be helpful for identifying patients at low risk. Novel models seem attractive for the high-risk normotensive PE but need to be externally validated then be assessed in impact studies.

\section{INTRODUCTION}

Venous thromboembolism (VTE), including pulmonary embolism (PE) and deep vein

\section{Strengths and limitations of this study}

- Comprehensive systematic review and meta-analysis of prognostic models in acute pulmonary embolism (PE) that was not restricted to only clinical prediction rules and derivation or validation studies, but was expanded to all available prediction/predictive models including update and impact studies to inform clinical decisions, with broad search strategy and predefined selection criteria, and no data or language restriction.

- Study quality assessed by using prognostic criteria more appropriate than diagnostic tools for prognostic studies and by using a domain approach, and full details on study characteristics provided.

- Quantitative analyses performed for 'both stable and unstable PE' and for 'stable PE', for each outcome/time point separately, and for every available risk cut-off for a model to assess how a model performs along the risk scale, and results provided in terms of summary estimates of proportion of risk groups and event rates within risk groups in 'absolute risk' more meaningful for clinicians and more appropriate for the study of prognosis, and summary estimates of sensitivity and specificity (accuracy).

- Not included in the systematic review because they deserve specific reviews, studies performed in selective populations such as in asymptomatic $P E$, unstable $P E$, patients with cancer, elderly patients, or studies restricted to only a single risk group (low-risk or high-risk group) with the exception of impact studies.

thrombosis (DVT), is a common and potentially fatal disorder, despite improvements in its management. The main short-term complications of $\mathrm{PE}$ are all-cause death, PE-related death, VTE events and bleeding.

In acute PE, there is a real clinical questioning and interest on how to choose the appropriate management for a specific patient. ${ }^{1-4}$ Usual care in the early phase is to treat patients in hospital and to use 
anticoagulants in normotensive patients or rescue thrombolysis in patients with hypotension or cardiogenic shock. In normotensive patients, other options are available that might depend on the estimated risk for adverse outcomes for the individual patient and include home treatment for patients at low risk, or closer monitoring and escalating therapy for patients at high risk.

Prognostic tools seek to classify patients by their risk of adverse outcomes to help select the appropriate management for an individual patient. The European Society of Cardiology 2008 guidelines $^{1}$ suggest using the haemodynamic status based on systolic blood pressure (SBP) and signs of right ventricular dysfunction (RVD) and ischaemia. The American Heart Association (AHA) Scientific Statement ${ }^{2}$ considers that patients with low-risk stable PE with no prognostic markers of RVD/ischaemia 'may still have significant rates of morbidity and mortality that are functions of older age and comorbidities'.

Systematic reviews of individual prognostic variables ${ }^{5-9}$ have shown inconsistent results across studies, leading to the development of prognostic models. The large number of studies of existing prognostic models and the differences between them suggest the need for a systematic review that could assess study quality, synthesise findings across studies, assess the validity of the original models and provide the best estimate from the model. Determining which prognostic models work, and which work best, may impact on clinical decisions and on research.

This systematic review assesses the characteristics and quality of studies of prognostic models in patients with acute PE. It investigates the performance and utility of the prognostic models, along their different phases of development in construction, validation, update and impact studies.

\section{METHODS}

\section{Selection criteria}

Criteria for considering studies for this review were derived from previous reviews of prognostic models. ${ }^{10-13}$ To be eligible, studies had to have developed a prognostic model to predict the outcome of patients with an acute symptomatic PE, with the specific aim of constructing a new prognostic model or validating, updating or studying the impact of an existing one. The models needed to contain a combination of at least two prognostic variables to predict patient outcome, incorporated from across the following characteristics: demographic/ clinical, biological and imaging related. Patient outcomes were death, PE-related death or VTE (DVT or $\mathrm{PE})$ recurrence. Only hospital-based studies were considered for inclusion.

Prognostic studies validating individual prognostic indicators, population-based studies, studies performed in selective populations (asymptomatic PE, unstable PE, patients with cancer, elderly patients, specific risk group except when assessed in impact studies) or considering only surrogate outcomes were not included. As they include prognostic and practical variables for hospitalisation, checklists of exclusion criteria from early discharge or home treatment were not considered strictly prognostic. Thus, studies on safety of early discharge or home treatment based on these criteria were not included unless their objective was clearly to derive and validate the checklist or to compare it with existing prognostic models. Unpublished articles or those published only as conference abstracts, discussion articles on prognostic models or indicators or patient management were not included. If a study was published more than once, the first published article or the article combining cumulative results from different studies was included.

\section{Search methods and search strategy}

Studies were sought through electronic databases: OVID versions of MEDLINE and EMBASE, and The Cochrane Library, from inception to July 2014. Given that there are many conference presentations in this area, we corresponded with authors and further searched in Google Scholar and other databases to check for pending or recently published full articles. The search also covered various sources of 'grey literature' to identify published, unpublished and ongoing studies (see online supplementary protocol-S). Further searches included the reference lists of relevant articles and books, citation indexes and hand-search of issues in relevant journals. There were no date or language restrictions on the searches.

The following Medical Subject Headings (MESH) terms and text words were used: pulmonary embolism. tw., exp Pulmonary Embolism/, exp Venous Thromboembolism/, prognos*.tw., exp Prognosis/, predict*.tw., cohort stud*.tw, exp Cohort Studies/, course.tw., exp Incidence/, score.tw., model*.tw., index. tw., rule.tw., criteria.tw., tool*.tw., severity index*.tw., geneva.tw., davies.tw. These were combined as shown in online supplementary box-s.

\section{Data collection}

Selection strategy

Potentially eligible studies were identified by examining titles and abstracts or other summaries as available. Full articles were obtained to assess eligibility criteria, before critical appraisal. Study identification was performed by two independent and blinded assessors to avoid selection bias. Disagreements were resolved through discussion.

\section{Data extraction content}

The data extraction form (online supplementary protocol-S) had six detailed sections: information about the review and verification of study eligibility, information about the study, assessment of study quality, assessment of methods relevant to the development phase of the model, general findings and results of model performance. 


\section{Data extraction management}

An electronic data collection form was created in Excel. An explanation for the data extraction items was available in corresponding cells, but there were no coding instructions. Contents were adjusted throughout the data extraction process. Data were extracted by one reviewer and checked by a second reviewer to obtain reliable information on study findings and study methodology. Disagreements were resolved by discussion.

\section{Dealing with missing data}

Study investigators were contacted by email for details not reported in the published reports. A standard data collection form was used to assist with this, when needed.

\section{Assessment of study quality}

All studies were assessed for methodological quality ${ }^{10} 13-18$ and risk of bias in regard to study design, analysis and reporting according to predefined criteria for type of study, sample of patients (proper formation of inception cohort, description of referral pattern), adequacy of prognostic factors, adequacy of outcome measures, blind assessment of outcomes, completeness of follow-up, sample size, treatment, missing data and adjustment for all potential confounders (online supplementary protocol-S).

Summary scores were not used to identify studies of high quality or low quality, ${ }^{17} 19$ but 'risk of bias' figures were produced to show the findings graphically.

\section{Data analysis}

The descriptive analysis addressed reporting on type and phase of development of the model, study characteristics, population and setting patterns, patient characteristics, prognostic information, prognostic modelling and other data analyses, and study quality.

Quantitative analyses were performed at each relevant model risk cut-off level for various outcomes and time points. These used data from model validation and model update studies, with and without the results of the model construction study. Outcomes were all-cause mortality, PE-related mortality, VTE recurrence, major or clinically relevant bleeding and composite outcomes. These were assessed for the duration of hospitalisation, at 1 and at 3 months. Summary estimates and their 95\% CIs were calculated for the population event rates, for the proportion of patients in risk categories and the incidence of events within risk categories, and were obtained as weighted average by the inverse variance method. When data were available from at least four studies, summary estimates of sensitivity and specificity and summary receiver operating characteristic (sROC) curves were obtained using the bivariate random-effects model. $^{2021}$

Studies that compared models either within the same article or in different articles or shared the same cohort in various model development phases were included once for the analysis of population event rates but as often as the number of prognostic models that were assessed for the analysis of risk group distribution, the incidence of events within risk groups and the prognostic performance of a model. Homogeneity of study designs, differences because of the case mix and statistical heterogeneity (Cochran's Q test, Higgins $\mathrm{I}^{2}$ statistic) were assessed to decide whether to combine the results of individual studies. When results were combined, a fixed-effects or a random-effects model was used depending on whether the effect was similar or variable across studies. The likely influence of the presence or absence of bias was examined in sensitivity analyses and funnel plots (observed and imputed studies, Egger's regression intercept). Subgroup analyses were performed for 'stable' and 'both stable and unstable' PE patient groups, 'prospective' or 'retrospective' studies and with regard to the phase of development (derivation, internal validation and external validation/ update) of studies.

Analysis was performed using metandi ${ }^{22}$ and GLLAMM $^{23}$ modules in Stata/SE (V.13.1), and using Comprehensive Meta-Analysis (CMA V.2. 2.064).

\section{Data synthesis}

To decide whether a prognostic model would be helpful for clinical practice, the following factors were required in external validation studies: direction and size of effect, and effect consistency across studies in the meta-analysis; and strength of evidence for the effect based on study quality and statistical measure of uncertainty. ${ }^{17}$ For a valid model to be acceptable, its utility should ideally have been demonstrated in an impact study, such as in a one-arm management study using the model or in a randomised trial comparing outcomes for patients in whom the model is used to inform decisionmaking and those for whom it is not used.

\section{RESULTS}

\section{Search results}

Figure 1 shows the flow of studies through the review following Preferred Reporting Items for Systematic Reviews and Meta-Analyses (PRISMA) guidelines. ${ }^{24}$ The numbers of potentially relevant records identified and screened in each database were 3127 in MEDLINE, 5819 in EMBASE and 1000 in The Cochrane Library. Most of these were not eligible because they were clearly not relevant (2711, 5276 and 945 , respectively) or because they did not meet selection criteria (328, 459 and 51, respectively). From 176 publications that were retained from these databases $(88,84$ and 4 , respectively) and from 10 additional publications from other sources, 75 were removed as duplicate records that had been found in more than one database and 40 were excluded for various reasons (figure 1): unmet criteria, ${ }^{25-48}$ duplicate, ${ }^{49-52}$ selective population, ${ }^{53-56}$ journal club,${ }^{57-59}$ comment letter ${ }^{60}$ algorithm, ${ }^{61}$ long-term 
Figure 1 Flow chart of search results.

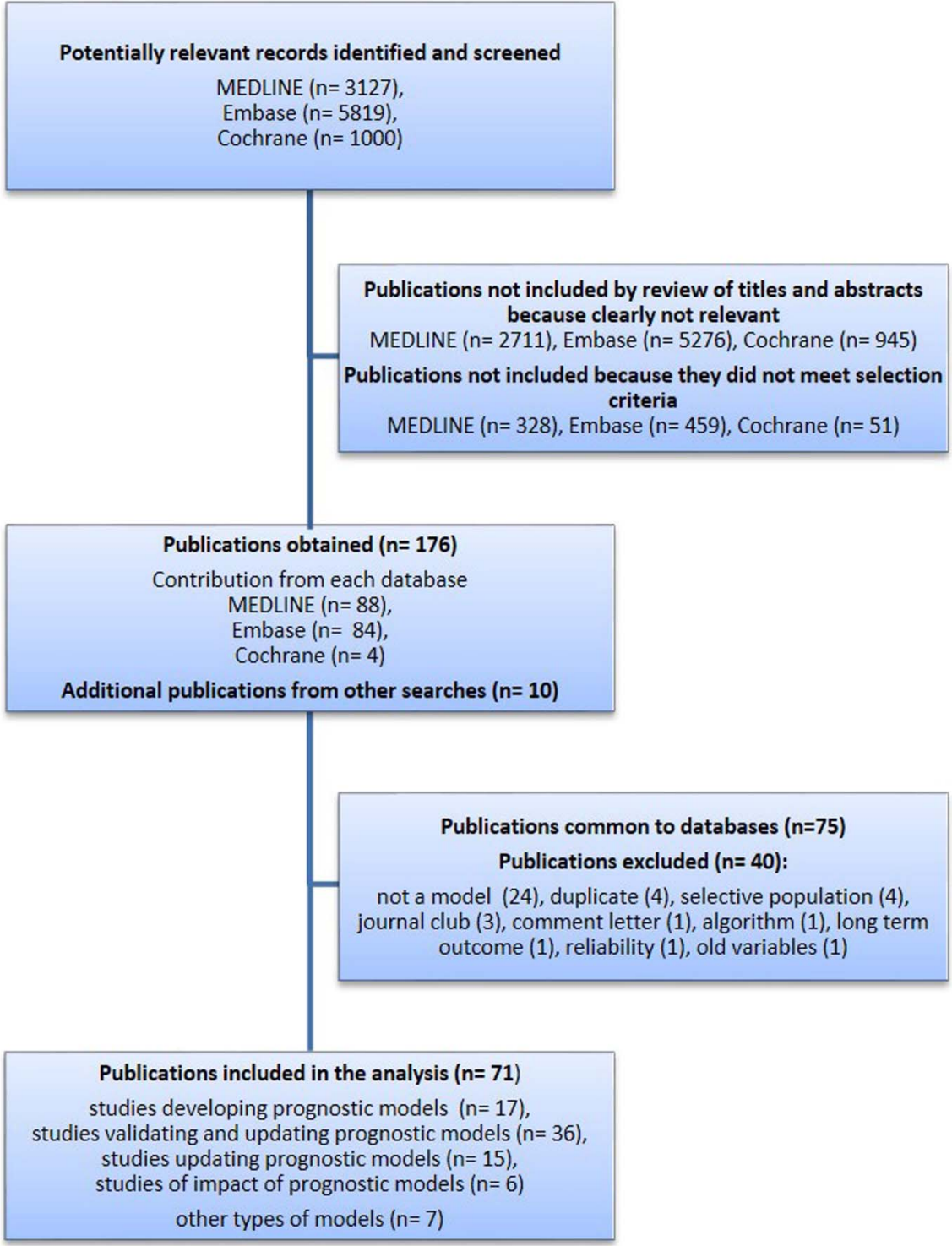

outcome, ${ }^{62}$ reliability study ${ }^{63}$ and very old variables in the model. ${ }^{64}$

Finally, 71 studies were included in the review, 62 from databases $^{65-126}$ and 9 from other sources that were mainly lists of references. ${ }^{127-135}$ Among studies included from databases, most were in MEDLINE and EMBASE, but four studies were not found in MEDLINE 768095102 and one study was not in EMBASE. ${ }^{77}$ Two studies were identified in The Cochrane Library, ${ }^{71}{ }^{100}$ but these were also found in MEDLINE and EMBASE. Some studies were based on retrospective analysis of prospectively collected data from previous diagnostic studies, ${ }^{136-141}$ one $^{137}$ of which was used in two model construction studies $^{6869}$ and two external validation studies. ${ }^{70} 97$

In total, among the 71 studies, 64 were found to be including variables specific to the domain of $\mathrm{PE}$ and its prognosis: 17 were identified as model construction studies, ${ }^{65} \quad 67-698587899092 \quad 110118 \quad 121-124 \quad 12913541$ as model external validation or model update

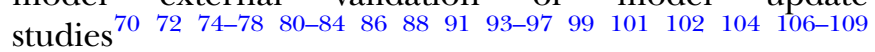

111-117 119120127130131134 and 6 as measuring model impact. $^{6671100128132133}$ For the remaining seven studies, variables in the model were either originally not specific to $\mathrm{PE}^{98} 103105$ or to its prognosis ${ }^{73}$ or concerned a hospital checklist ${ }^{79125126}$ that is a combination of prognostic and practical variables for outpatient management.

\section{Descriptive analysis}

\section{Prognostic models}

We identified three types of models related to risk stratification of patients with PE (table 1 and see online supplementary table S1). Type 1 model includes variables specific to the domain and the prognosis of PE. Type 2 applies models that are used in other domains such as the Global Registry of Acute Coronary Events $\left(\right.$ GRACE) ${ }^{103}$ or the Charlson Comorbidity Index, ${ }^{98} 105$ or applies diagnostic prediction rules ${ }^{73}$ for the assessment of PE prognosis. Type 3 models incorporate hospital checklist variables as exclusion criteria from early discharge or home treatment. ${ }^{79125126}$ 
Table 1 Variables used in the original prognostic models-prognostic variables included in the final models (only type 1 prognostic models presented) and points assigned (in numbers) to each variable when applied. Rule stands for scoring rule, score for simplified scoring rule or scoring system

\begin{tabular}{|c|c|c|c|c|c|c|c|c|c|c|c|c|c|c|c|c|c|}
\hline $\begin{array}{l}\text { Models } \\
\text { Model construction } \\
\text { studies (derivation } \\
\text { samples) }\end{array}$ & $\begin{array}{l}\text { GPS } \\
(\text { Wicki } \\
\left.\text { et } a^{\prime 22}\right)\end{array}$ & $\begin{array}{l}\begin{array}{l}\text { No } \\
\text { acronym } \\
\text { (Polish } \\
\text { model) }\end{array} \\
\text { (Kostrubiec } \\
\text { et } a^{P^{0}} \text { ) }\end{array}$ & $\begin{array}{l}\text { PESI } \\
(\text { Aujesky } \\
\left.\text { et } a^{f^{8}}\right)\end{array}$ & $\begin{array}{l}\text { PE } \\
\text { Prognostic } \\
\text { Algorithm } \\
\text { (Aujesky } \\
\text { et } a f^{69} \text { ) }\end{array}$ & $\begin{array}{l}\text { No } \\
\text { acronym } \\
\text { (Spanish } \\
\text { model) } \\
\text { (Uresandi } \\
\text { et al }{ }^{118} \text { ) }\end{array}$ & $\begin{array}{l}\text { No } \\
\text { acronym } \\
\text { (Dutch } \\
\text { model) } \\
\text { (Agterof } \\
\text { et } a^{f^{7}} \text { ) }\end{array}$ & $\begin{array}{l}\text { EMEP } \\
\text { (Volschan } \\
\left.\text { et }\left.a\right|^{121}\right)\end{array}$ & 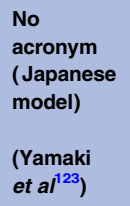 & 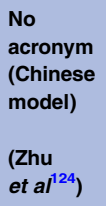 & $\begin{array}{l}\text { Simplified } \\
\text { PESI } \\
(\text { Jimenez } \\
\left.\text { et }\left.a\right|^{\beta 5}\right)\end{array}$ & $\begin{array}{l}\text { PREP } \\
\text { (Sanchez } \\
\left.\text { et } a f^{10}\right)\end{array}$ & $\begin{array}{l}\text { UPS } \\
\text { (Agterof } \\
\text { et } a^{55} \text { ) }\end{array}$ & $\begin{array}{l}\text { No } \\
\text { acronym } \\
\text { (Huang } \\
\left.\text { et } a f^{29}\right)\end{array}$ & $\begin{array}{l}\text { Simple Score } \\
\text { FAST } \\
\text { (Lankeit } \\
\text { et } a^{\beta^{2}} \text { ) and } \\
\left(\text { Dellas et } a^{\beta 0} \text { ) }\right.\end{array}$ & $\begin{array}{l}\text { SIRS-WCC } \\
\text { (Jo } \\
\text { et } a^{\beta 9} \text { ) }\end{array}$ & $\begin{array}{l}\text { No } \\
\text { acronym } \\
\text { (Bova } \\
\text { et } a l^{135} \text { ) }\end{array}$ & $\begin{array}{l}\text { eStiMaTe } \\
\text { (PROTECT) } \\
\text { (Jiménez } \\
\text { et } \boldsymbol{a}^{\beta 7} \text { ) }\end{array}$ \\
\hline $\mathrm{N}$ of candidate variables & 14 & NR & 29 & 29 & $>30$ & 7 & 20 & 16 & NR & 11 & $>30$ & 7 & 38 & NR & NR & Unclear & 13 \\
\hline $\begin{array}{l}N \text { of variables in final } \\
\text { model }\end{array}$ & 6 & 2 & 11 & 10 & 7 & 2 & 5 & 7 & 8 & 6 & 5 & 4 & 4 & 3 & 4 & 4 & 4 \\
\hline $\begin{array}{l}\text { Proposed risk } \\
\text { assessment method }\end{array}$ & Score & Rule & Score & Rule & Score & Rule & Score & Score & Equation & Score & Score & Rule & Score & Score & None & Score & Calculator \\
\hline
\end{tabular}

assessment methoc

Type of selected Total

variables in final model $\mathrm{N}^{*}$

Demographic and clinical characteristics

Age

Gender (male sex)

Syncope

Leg symptoms

rest

No recent surgery

Active cancer

Metastatic cancer

Non-metastatic canc

Previous DVT/PE

Heart failure

Chronic lung disease

Chronic cor pulm
Heart failure or

chronic lung disease

Chronic renal disease

Cerebrovascular

disease

Recent bleedin

Inadequate

anticoagulatio

Clinical findings

Cardiogenic shock

HR

SBP

RR
Temperature

Altered mental status

$\mathrm{PaO}_{2} / \mathrm{SpO}_{2}$

Accentuation of $\mathrm{P2}$

Laboratory findings

WCC

Creatinine

CPK

cTnl
cTnT

cTnT
hscTn

cTn

$\begin{array}{lll}\text { characteristics } & \text { Age, in } \quad x & 1\end{array}$

year
10

$2 \quad 10$

2

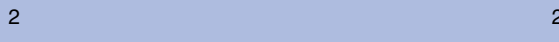

2

2

3

1

1
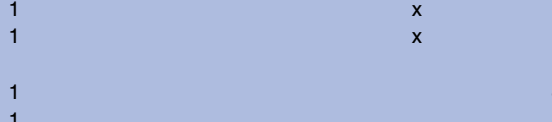

2

62

3
2
4

(1)

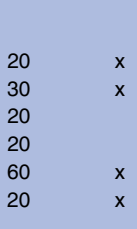

3 


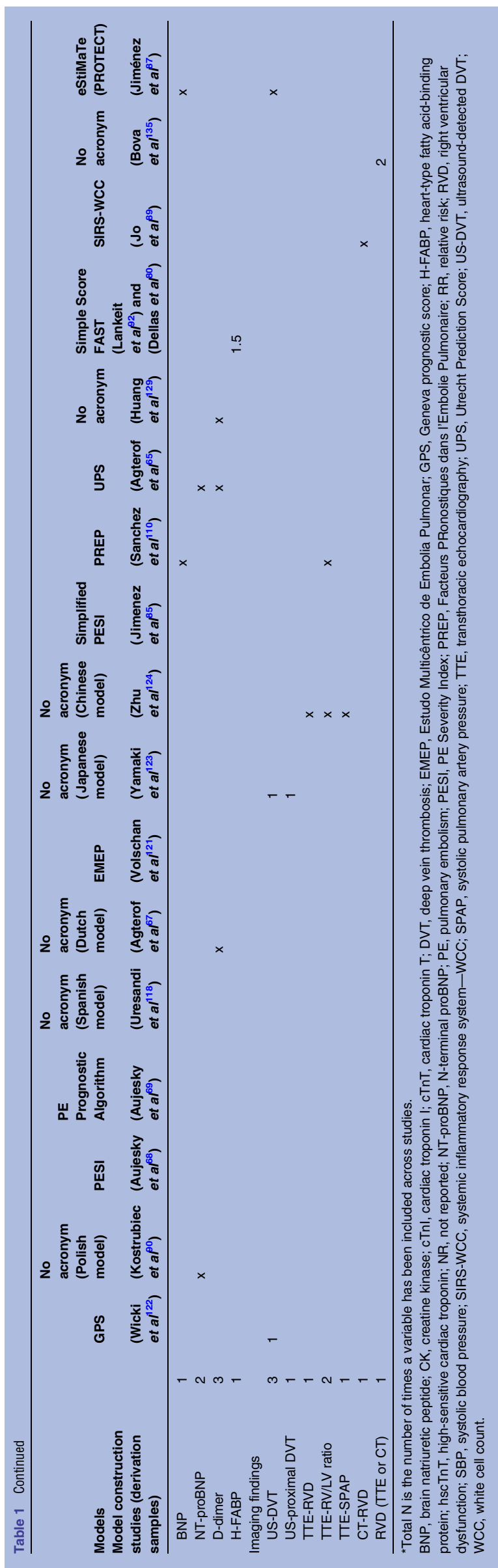

Among the 17 'type 1' prognostic models that were identified in model construction studies, $8^{68} 69858792110118122$ underwent external validation or were updated; some of them in many studies. Three $^{68118122}$ were assessed in impact studies. ${ }^{71} 100128$ There are two other models that were tested in impact studies, ${ }^{66} 132$ without being previously reported in a construction study. Table 1 shows that the variables that were mostly included in final models were in descending order: heart rate, active cancer, age, SBP, peripheral oxygen saturation and altered mental status.

Most of the studies identified for this review were external validation or update studies.

\section{Study characteristics}

Research objective, type of study and study design, setting, country, number of participating centres, patients (age, sex and haemodynamic status), outcomes, time points and corresponding event rates are displayed in online supplementary tables S2.1-S2.5.

In model construction studies $(\mathrm{n}=17)$ (see online supplementary table S2.1), the objective was usually to riskstratify patients (13 studies) rather than to identify low-risk patients. Nine studies were prospective, seven reported on stable PE subgroup and seven were prospective and concerned stable PE as well. In 8 studies, patients were recruited in emergency departments (EDs) and in 13 studies, inception started on admission. Nine were multicenter studies. The PE Severity Index $(\text { PESI })^{68}$ and Prognostic Algorithm ${ }^{69}$ cohort included the largest derivation and internal validation sets, but the study was retrospective, had missing data and lack of information on PE diagnosis and on the type of treatment received. Four studies ${ }^{87} 110121135$ were sound methodologically and clinically relevant and present the following characteristics: prospective multicenter study, inception on admission, patients from ED, patients with stable PE reported, adequate early outcome and time point.

In model external validation studies $(n=36)$ (see online supplementary table S2.2), the main objective was to identify low-risk patients. The other objectives were to assess added value of prognostic variables, head-to-head comparison or identification of patients with stable $\mathrm{PE}$ at high risk. Among the prospective studies $(n=9)$ in stable and unstable PE, one study ${ }^{102}$ validated the European Society of Cardiology (ESC) model in terms of 30-day mortality and the other one compared Hestia checklist criteria with simplified PESI (sPESI) in terms of 7-day, 30-day and 3-month death; in stable PE, Geneva prognostic score (GPS), ${ }^{74}$ PESI, ${ }^{104} 111$ sPESI, ${ }^{80}{ }^{101}$ ESC $^{72}{ }^{80}$ FAST $^{80}$ and eStiMaTe ${ }^{87}$ models were validated in seven studies, of which one study ${ }^{80}$ compared three models FAST, sPESI and ESC. Reliability was also assessed in two studies. ${ }^{75} 106$

Model update studies $(\mathrm{n}=15)$ (see online supplementary table S2.3) assessed the value of adding a two-test or a three-test strategy to PESI, based on a combination of 
RVD, cardiac troponin I (cTnI) and ultrasound (US)-detected DVT, to identify patients with high-risk $\mathrm{PE} ;{ }^{86}$ assessed the additive value of CT-RVD to Hestia, ${ }^{126}$ the additive value of transthoracic echocardiography (TTE)-RVD, ${ }^{111}$ brain natriuretic peptide $(\mathrm{BNP})^{111}$ or cTnI to PESI, ${ }^{104111}$ or TTE-RVD and BNP to Facteurs PRonostiques dans l'Embolie Pulmonaire (PREP), ${ }^{110}$ or the additive value of cardiac troponin $\mathrm{T}(\mathrm{cTnT}),{ }^{101}$ highsensitive $\mathrm{cTnT}^{94} 101$ or N-terminal proBNP (NT-proBNP) ${ }^{95}$ to sPESI, in order to identify patients at lower risk or at higher risk; or assessed the effect of cause of death classification on SPESI whether combined or not to cTnI. ${ }^{109}$ Eight studies were prospective and specific to stable PE. Retrospective studies assessed the additive value of CT-RVD, ${ }^{112}$ of white cell count (WCC) and systemic inflammatory response syndrome (SIRS), ${ }^{89}$ of NT-proBNP, cTnI or CT-RVD ${ }^{77}$ to PESI; the additive value of cTn to $^{\text {PESI }}{ }^{96}$ or to sPESI; ${ }^{115}$ and the additive value of TTE-RVD to Shock Index. ${ }^{117}$

Six studies measured model impact (see online supplementary table S2.4). Four were performed in patients identified as low risk by the model, assessing the safety of early discharge or outpatient treatment. This was done in a one-arm management study for GPS ${ }^{128}$ and NT-proBNP, ${ }^{66}$ and in a randomised controlled trial (RCT) where outpatient management was compared with standard hospitalisation (inpatient treatment) either by using the Spanish model ${ }^{100}$ or by using PESI in the Outpatient Treatment of Pulmonary Embolism (OTPE) study. ${ }^{71}$ The Pulmonary Embollsm THrOmbolysis (PEITHO) randomised double-blind trial $^{132}$ assessed the role of fibrinolytic therapy tenecteplase in normotensive patients with $\mathrm{PE}$ considered at intermediate-high risk by TTE-RVD or CT-RVD, and myocardial injury as indicated by a positive test for cTnI or cTnT. Another study assessed the use and the impact of model-based risk stratification on treatment decisions and outcome in clinical practice. ${ }^{133}$ All studies were multicenter and prospective except the latter, which was a single-centre and retrospective study.

\section{Study quality}

Quality of individual studies and a summary of study quality at different model development phases are shown in online supplementary figures S1.1 to S6.2.

Among model construction studies (see online supplementary figures S1.1 and S1.2), PREP, ${ }^{110}$ esTiMaTe $^{87}$ and Bova's study ${ }^{135}$ models satisfied most of the study quality criteria. Criteria that were often met (in at least $70 \%$ of the included studies) are: inclusion criteria definition, characteristics description, length of follow-up and criteria about the outcome (objectiveness, full definition, appropriateness, proportion of patients with known outcome). Criteria that were least often met (in $<30 \%$ of the included studies) are: sample completeness (selection bias), reasons for lost to follow-up reporting, similarity of outcome assessment for all study participants, differences with participants who did not complete the study, availability of prognostic variables and justification of sample size.

In model validation studies (see online supplementary figures S2.1 and S2.2), including those that also updated the model, the most recent validation studies ${ }^{87} 101102111$ satisfied most of the study quality criteria. The most often met criteria concerned specification of inclusion criteria, sample selection, population characteristics description, follow-up, outcome (objective, fully defined, appropriate, known for a high proportion of patients), and full definition of prognostic variables and description of treatment. Major concerns were about sample completeness, reporting on reasons for lost to follow-up and differences with participants who did not complete the study, justification of sample size and statistical analysis.

In model update studies (see online supplementary figures s3.1 and s3.2), three studies ${ }^{95} 101{ }^{111}$ satisfied most of the criteria. The summary of study quality shows that most of the criteria were often met, but there are concerns about sample completeness and reporting on reasons for lost to follow-up and differences with participants who did not end the study, justification of sample size and how lost to follow-up treated.

Model impact studies (see online supplementary figures S4.1 and S4.2) had the best compliance with study quality criteria, with most of the key factors provided. $^{6671100132}$

For type 2 and 3 studies, the number of studies is too small to draw general conclusions. In type 2 studies (see online supplementary figures S5.1 and S5.2), although inclusion was well defined, there are problems with sample selection and sample completeness in all $^{98} 103105$ but one study, ${ }^{73}$ in justification of sample size and data analysis. In type 3 studies (see online supplementary figures S6.1 and S6.2), the main concerns are about a lack of information on reasons for lost to follow-up, justification of sample size and data analysis (missing data, lost to follow-up, statistical adjustment).

\section{Quantitative analysis}

Population event rates

There were a total of 44298 patients if patients in the cohorts account once, only regardless of how many studies reported those patients, and if impact studies that involved only low-risk or intermediate-risk patients are excluded.

Analysis based on inverse-variance method with random-effects model (see online supplementary table S3) showed overall in-hospital, 30-day and 3-month point estimate to be $6.5 \%$ (95\% CI $4.9 \%$ to $8.5 \%)$ (20 studies), $7.4 \%$ (6.5\% to $8.5 \%$ ) (32 studies) and $6.8 \%$ (5.7\% to $8.1 \%$ ) (11 studies), respectively, for mortality; $3.1 \%$ (2.6\% to $3.8 \%$ ) (7 studies), $4.0 \%$ (3.2\% to $5.0 \%)$ (15 studies) and $2.9 \%$ (2.2\% to $3.7 \%$ ) (6 studies), respectively, for PE-related mortality; and $0.2 \%(0.0 \%$ to $1.5 \%$ ) (3 studies), $1.1 \%$ ( $0.7 \%$ to $1.8 \%$ ) (6 studies) and $2.6 \%$ (1.6\% to $4.4 \%$ ) (4 studies), respectively, for VTE 
recurrence. Composite event rates, major and non-major clinically relevant bleeding and fatal bleeding are also displayed.

\section{Risk groups}

\section{All-cause mortality}

The distribution of risk groups for a model (proportion of patients in low-risk or in high-risk groups) according to specified cut-off levels and the incidence of all-cause mortality within risk groups, expressed in \% (95\% CI), are shown in detail (table 2). The following paragraphs summarise the findings.

For GPS $\geq 3$ vs GPS $\leq 2$ cut-off, mortality was reported only in a single external validation study; the prevalence of the low-risk group is $82 \%$ ( $77.3 \%$ to $85.9 \%)$, and the incidence of 30-day mortality in the low-risk group is $9.8 \%(3.2 \%$ to $26.6 \%)$. The prevalence of high-risk group is $18 \%$ ( $14.1 \%$ to $22.7 \%)$ and the incidence of 30-day mortality is $20.1 \%$ (11.4\% to $33 \%)$.

For $\mathrm{PESI} \geq \mathrm{III}$ vs $\mathrm{PESI} \leq \mathrm{II}$ cut-off, the overall prevalence of low-risk group is $43.1 \%$ (39.6\% to $46.6 \%)$ and the overall in-hospital, 30-day and 3-month mortality rates within low-risk group are $1.4 \%(1.2 \%$ to $1.8 \%)$ (5 studies), $2.3 \%$ (1.7\% to $2.9 \%)$ (9 studies) and $1 \%(0.5 \%$ to $1.8 \%$ ) (6 validation studies), respectively. The overall prevalence of high-risk patients is $56.9 \% \quad(53.4 \%$ to $60.4 \%)$ and the overall in-hospital, 30-day and 3-month mortality rates are $9.3 \%(8.4 \%$ to $10.4 \%), 11.4 \%(9.9 \%$ to $13.1 \%$ ) and $13.0 \%$ (8.7\% to $18.9 \%)$, respectively. Summary estimate of the prevalence and the mortality rates from external validation studies are consistent with those of the derivation and internal validation samples.

For sPESI, the overall prevalence of low-risk group is $36.3 \%$ (33.3\% to $39.4 \%)$. The overall in-hospital, 30-day and 3-month mortality rates are $0.3 \%(0 \%$ to $2.3 \%$ ) (2 external validation studies), $1.5 \%(0.9 \%$ to $2.5 \%)$ (11 studies) and $0.8 \%$ (0.3\% to $2.2 \%$ ) (3 external validation studies), respectively. The overall proportion of high-risk patients is $63.7 \%(60.6 \%$ to $66.7 \%)$ and the overall in-hospital, 30-day and 3-month mortality rates are 3.2\% (1.6\% to $6.4 \%), 10.7 \%$ (8.8\% to $12.9 \%)$ and $13.6 \%$ (8.8\% to $20.3 \%)$, respectively. Results are consistent across derivation, internal validation and external validation samples.

With the algorithm (4 studies), 22\% (19.3\% to $24.9 \%$ ) of patients are classified as low risk. The in-hospital and 30-day mortality rates are $0.6 \%(0.4 \%$ to $1 \%)$ and $1.1 \%$ $(0.5 \%$ to $2.1 \%)$, respectively. The results in the validation and the derivation samples are similar.

For the PREP model (mortality reported in 1 external validation study), $67.2 \%(61.7 \%$ to $72.3 \%)$ of patients are classified as low risk. The 30-day and 3-month mortality rates are $1 \%(0.2 \%$ to $3.9 \%)$ and $1.5 \%(0.5 \%$ to $4.5 \%)$, respectively, in the low-risk group, and $7.1 \%$ (3.4\% to $14.1 \%$ ) and 9.1 (4.8 to 16.6), respectively, in the high-risk group. In the original study, the incidence of a 30-day composite outcome is $2.5 \%$ (1.2\% to $4.9 \%)$, $37.3 \%(33.2 \%$ to $41.5 \%)$ of patients are classified as high risk and the incidence of events is $17.7 \%$ (12.9\% to $23.8 \%$ ).

Shock Index classifies $80.3 \%$ (68\% to $88.7 \%)$ of patients in the low-risk group, but with a high 30-day mortality rate of $10.7 \%(6.1 \%$ to $17.9 \%)$ and $24.1 \%$ $(13.6 \%$ to $39.1 \%)$ in the high-risk group.

With ESC, the low-risk group prevalence is $89.8 \%$ (72.7\% to $96.7 \%)$; the in-hospital and 30-day mortality rates are $5 \%(3.6 \%$ to $7.1 \%$ ) (3 studies) and $8.9 \%(4.7 \%$ to $16.5 \%$ ) (1 study), respectively, in the low-risk group, and $41.1 \%(22.7 \%$ to $62.5 \%)$ and $26.5 \%$ (16.1\% to $40.4 \%$ ), respectively, in the high-risk group. These results apply for 'both stable and unstable' patients. For the stable PE patient subgroup, for 'intermediate-high' risk cut-off (intermediate-high-risk patients have RVD and myocardial injury, and the lower risk that includes intermediate-low-risk and low-risk groups either one of them or none), the proportion of the lower risk group is $74.4 \%$ (52.4\% to $88.5 \%$ ) (5 studies) and the in-hospital mortality rate is $3.1 \%(1.4 \%$ to $6.8 \%)$ in the lower risk group and $7.7 \%(4.7 \%$ to $12.2 \%)$ in the intermediatehigh-risk group.

Given the high event rate within the 'low-risk' groups from Shock Index and ESC, these would not qualify as suitable for the identification of a low-risk but of a 'highrisk' patient group.

The performance of other models recently constructed is discussed in model update section.

\section{Outcomes other than all-cause mortality}

Tables 3 and 4 show summary estimates with results from studies that report outcomes in terms of PE-related death, adverse outcome (clinical deterioration, haemodynamic collapse), VTE and their combinations in 'both stable and unstable' (table 3), and separately in 'stable' (table 4) patient groups. Although many studies were retrospective or were single studies, the results confirm the predictive ability for PESI and sPESI at the optimal cut-offs or less, preferably in combination with biomarkers, for identifying patients at low risk for these specific outcomes as well, mainly in stable PE. They also confirm the ability for some models at higher cut-offs for identifying patients at very high risk (30-day event rate over $20 \%$ ) such as PREP-Clin $\geq$ III without or with BNPTTE-RVD, PESI $\geq$ IV, PESI V without or with TTE-RVD, ESC high, Shock Index, eStiMaTe high, FAST 3, Bova stage III. Most of the models combine biomarkers or imaging-based modalities to clinical variables or to preexisting models. In most of the studies, the proportion of patients at very low or at very high risk is low.

\section{Type 2 and type 3 model studies}

Table 5 shows the results of type 2 and type 3 model studies. Revised Geneva score ${ }^{73}$ (RGS) and simplified Geneva score $^{73}$ (SGS) originally dedicated for the diagnosis of PE may provide at low cut-offs a small 3-month mortality rate $(0.9 \%(0.1 \%$ to $12.3 \%))$ in patients at low risk. Similarly, at the lowest cut-offs, GRACE ACS ${ }^{103}$ and 
Table 2 In-hospital, 30-day and 3-month all-cause mortality, and distribution of risk groups for relevant risk cut-offs

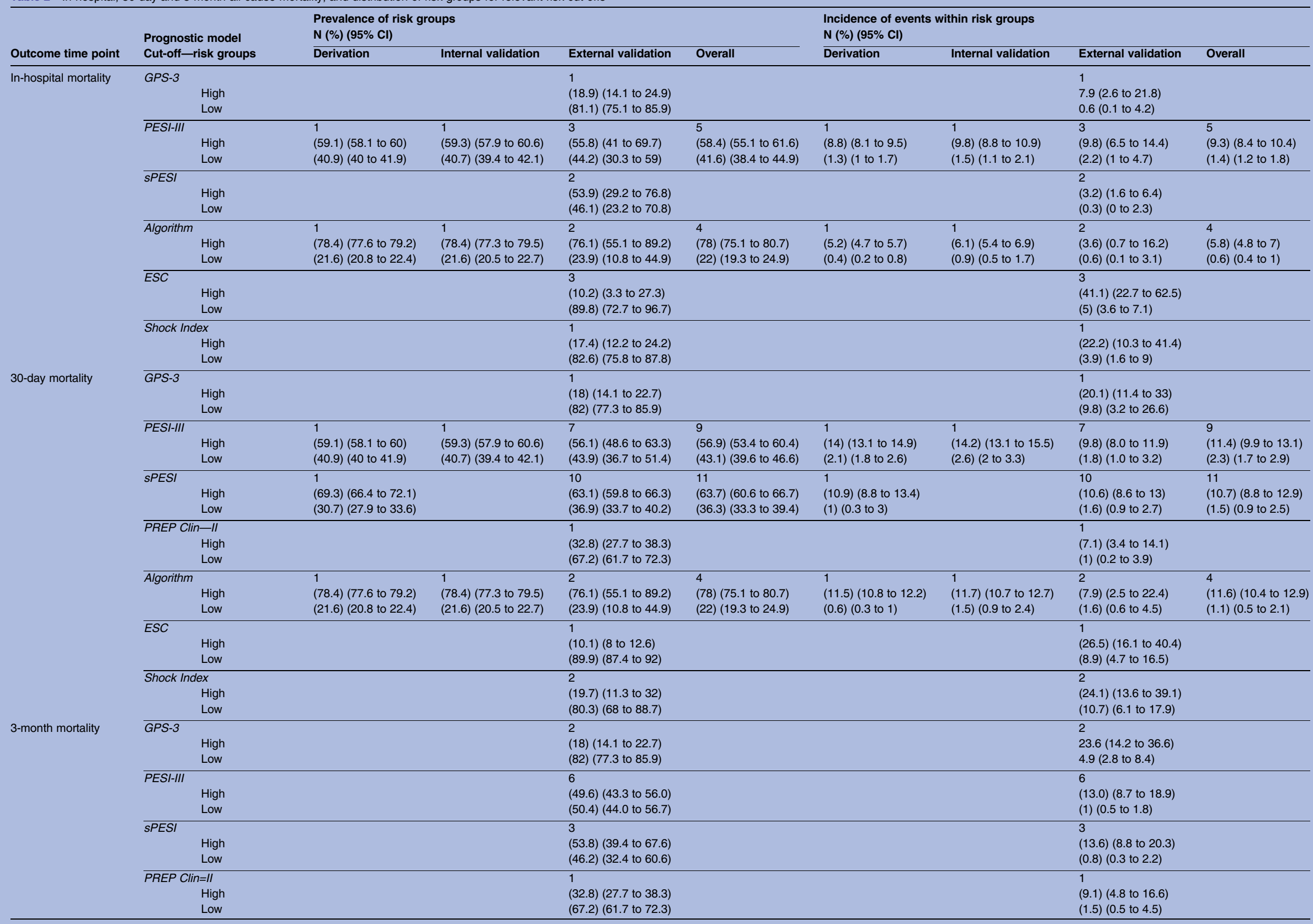

ESC, European Society of Cardiology; GPS, Geneva prognostic score; N, number of studies; PESI, Pulmonary Embolism Severity Index; PREP, Facteurs PRonostiques dans l'Embolie Pulmonaire; sPESI, simplified PESI. 
Table 3 PE-related death, adverse outcome (death, clinical deterioration or haemodynamic collapse), VTE, major bleeding and their combinations in "both stable and unstable' PE patient risk groups

\begin{tabular}{|c|c|c|c|c|c|c|c|c|}
\hline Risk cut-off (author, year) & $\begin{array}{l}\text { Development } \\
\text { phase }\end{array}$ & $\begin{array}{l}\text { N } \\
\text { studies }\end{array}$ & $\begin{array}{l}\text { Type of } \\
\text { study }\end{array}$ & $\begin{array}{l}\text { Haemodynamic } \\
\text { status }\end{array}$ & Outcome & $\begin{array}{l}\text { Time } \\
\text { point }\end{array}$ & $\begin{array}{l}\text { Proportion } \\
(95 \% \mathrm{Cl}) \\
\text { High-risk group } \\
\text { Low-risk group }\end{array}$ & $\begin{array}{l}\text { Event rate } \\
(95 \% \mathrm{Cl}) \\
\text { High-risk group } \\
\text { Low-risk group }\end{array}$ \\
\hline $\begin{array}{l}\text { Algorithm } \geq 1 \\
\text { (Jakobsson et al 2010) }^{130}\end{array}$ & $\begin{array}{l}\text { External } \\
\text { validation }\end{array}$ & 1 & Retrospective & Not reported & PE-related death & 30 days & $\begin{array}{l}83.7(81.3 \text { to } 85.9) \\
16.3(14.1 \text { to } 18.7)\end{array}$ & $\begin{array}{l}6.6(5.1 \text { to } 8.5) \\
0.6(0.1 \text { to } 4.3)\end{array}$ \\
\hline $\begin{array}{l}\text { Agterof (Herat rate-Ddimer) } \\
\text { (Agterof et al 2009) }^{67}\end{array}$ & Derivation & 1 & Retrospective & $\begin{array}{l}\text { Both stable and } \\
\text { unstable }\end{array}$ & $\begin{array}{l}\text { Death VTE major } \\
\text { bleeding }\end{array}$ & In-hospital & $\begin{array}{l}67.1(61.7 \text { to } 72.1) \\
32.9(27.9 \text { to } 38.3)\end{array}$ & $\begin{array}{l}5.3 \text { (3.0 to } 9.3) \\
0.5 \text { (0 to } 7.3)\end{array}$ \\
\hline $\begin{array}{l}\text { ESC high } \\
(\text { Vanni et al 2011) }\end{array}$ & $\begin{array}{l}\text { External } \\
\text { validation }\end{array}$ & 1 & Retrospective & $\begin{array}{l}\text { Both stable and } \\
\text { unstable }\end{array}$ & PE-related death & In-hospital & $\begin{array}{l}5.6 \text { (3.8 to } 8) \\
94.4(92 \text { to } 96.2)\end{array}$ & $\begin{array}{l}29.6(15.6 \text { to } 49) \\
4.1(2.7 \text { to } 6.4)\end{array}$ \\
\hline $\begin{array}{l}\text { ESC intermediate-high } \\
(\text { Vanni et al 2011) }\end{array}$ & $\begin{array}{l}\text { External } \\
\text { validation }\end{array}$ & 1 & Retrospective & $\begin{array}{l}\text { Both stable and } \\
\text { unstable }\end{array}$ & PE-related death & In-hospital & $\begin{array}{l}60(55.6 \text { to } 64.3) \\
40(35.7 \text { to } 44.4)\end{array}$ & $\begin{array}{l}8.6(5.9 \text { to } 12.4) \\
1(0.3 \text { to } 4)\end{array}$ \\
\hline $\begin{array}{l}G P S \geq 1 \\
(\text { Wicki et al 2000) }\end{array}$ & Derivation & 1 & Retrospective & Not reported & $\begin{array}{l}\text { Death VTE major } \\
\text { bleeding }\end{array}$ & 3 months & $\begin{array}{l}80.6(75.4 \text { to } 84.9) \\
19.4(15.1 \text { to } 24.6)\end{array}$ & $\begin{array}{l}12.5(8.7 \text { to } 17.6) \\
0.9(0.1 \text { to } 13.4)\end{array}$ \\
\hline$(\text { Nendaz et al 2004) })^{97}$ & $\begin{array}{l}\text { External } \\
\text { validation } \\
\text { Overall }\end{array}$ & $\begin{array}{l}1 \\
2\end{array}$ & Retrospective & Unclear & $\begin{array}{l}\text { Death VTE major } \\
\text { bleeding } \\
\text { Death VTE major } \\
\text { bleeding }\end{array}$ & $\begin{array}{l}3 \text { months } \\
3 \text { months }\end{array}$ & $\begin{array}{l}71.4(64.7 \text { to } 77.2) \\
28.6(22.8 \text { to } 35.3) \\
76.3(66.1 \text { to } 84.2) \\
23.7(15.8 \text { to } 33.9)\end{array}$ & $\begin{array}{l}12.0(7.6 \text { to } 18.4) \\
3.5(0.9 \text { to } 13.0) \\
12.3(9.3 \text { to } 16.1) \\
2.7(0.8 \text { to } 8.9)\end{array}$ \\
\hline 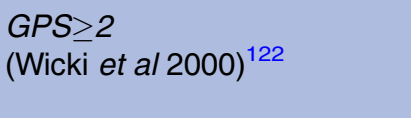 & Derivation & 1 & Retrospective & Not reported & $\begin{array}{l}\text { Death VTE major } \\
\text { bleeding }\end{array}$ & 3 months & $\begin{array}{l}51.1(45.1 \text { to } 57.1) \\
48.9(42.9 \text { to } 54.9)\end{array}$ & $\begin{array}{l}18.2(12.6 \text { to } 25.6) \\
1.5(0.4 \text { to } 5.9)\end{array}$ \\
\hline$\left(^{\text {Nendaz et al 2004) }}\right)^{97}$ & $\begin{array}{l}\text { External } \\
\text { validation } \\
\text { Overall }\end{array}$ & $\begin{array}{l}1 \\
2\end{array}$ & Retrospective & Unclear & $\begin{array}{l}\text { Death VTE major } \\
\text { bleeding } \\
\text { Death VTE major } \\
\text { bleeding }\end{array}$ & $\begin{array}{l}3 \text { months } \\
3 \text { months }\end{array}$ & $\begin{array}{l}44.2(37.5 \text { to } 51.2) \\
55.8(48.8 \text { to } 62.5) \\
47.9(41.2 \text { to } 54.7) \\
52.1(45.3 \text { to } 58.8)\end{array}$ & $\begin{array}{l}18.2(11.4 \text { to } 27.6) \\
2.7(0.9 \text { to } 8.0) \\
18.2(13.7 \text { to } 23.8) \\
2.1(0.9 \text { to } 51)\end{array}$ \\
\hline $\begin{array}{l}G P S \geq 3 \\
\left(_{\text {Wicki et al 2000 })^{122}}\right.\end{array}$ & Derivation & 1 & Retrospective & Not reported & $\begin{array}{l}\text { Death VTE major } \\
\text { bleeding }\end{array}$ & 3 months & $\begin{array}{l}32.8(27.5 \text { to } 38.7) \\
67.2(61.3 \text { to } 72.5)\end{array}$ & $\begin{array}{l}26.1(18.0 \text { to } 36.3) \\
2.2(0.8 \text { to } 5.8)\end{array}$ \\
\hline$(\text { Nendaz et al 2004) })^{97}$ & $\begin{array}{l}\text { External } \\
\text { validation } \\
\text { Overall }\end{array}$ & 2 & Retrospective & Unclear & $\begin{array}{l}\text { Death VTE major } \\
\text { bleeding } \\
\text { Death VTE major } \\
\text { bleeding }\end{array}$ & $\begin{array}{l}3 \text { months } \\
3 \text { months }\end{array}$ & $\begin{array}{l}20.1 \text { (15.1 to } 26.2) \\
79.9(73.8 \text { to } 84.9) \\
26.2(15.6 \text { to } 40.5) \\
73.8 \text { (59.5 to } 84.4)\end{array}$ & $\begin{array}{l}27.5(15.9 \text { to } 43.2) \\
5.0(2.5 \text { to } 9.7) \\
26.6(19.6 \text { to } 34.9) \\
3.6(1.6 \text { to } 7.8)\end{array}$ \\
\hline $\begin{array}{l}G P S \geq 4 \\
(\text { Wicki et al 2000) }\end{array}$ & Derivation & 1 & Retrospective & Not reported & $\begin{array}{l}\text { Death VTE major } \\
\text { bleeding }\end{array}$ & 3 months & $\begin{array}{l}11.9(8.6 \text { to } 16.4) \\
88.1(83.6 \text { to } 91.4)\end{array}$ & $\begin{array}{l}40.6(25.3 \text { to } 58.1) \\
5.9(3.5 \text { to } 9.8)\end{array}$ \\
\hline$\left(\right.$ Nendaz et al 2004) ${ }^{97}$ & $\begin{array}{l}\text { External } \\
\text { validation }\end{array}$ & 1 & Retrospective & Unclear & $\begin{array}{l}\text { Death VTE major } \\
\text { bleeding }\end{array}$ & 3 months & $\begin{array}{l}8.0(5.0 \text { to } 12.7) \\
92.0(87.3 \text { to } 95.0)\end{array}$ & $\begin{array}{l}31.3(13.6 \text { to } 56.7) \\
7.7(4.6 \text { to } 12.5)\end{array}$ \\
\hline
\end{tabular}




\begin{tabular}{|c|c|c|c|c|c|c|c|c|}
\hline Risk cut-off (author, year) & $\begin{array}{l}\text { Development } \\
\text { phase }\end{array}$ & $\begin{array}{l}\mathbf{N} \\
\text { studies }\end{array}$ & $\begin{array}{l}\text { Type of } \\
\text { study }\end{array}$ & $\begin{array}{l}\text { Haemodynamic } \\
\text { status }\end{array}$ & Outcome & $\begin{array}{l}\text { Time } \\
\text { point }\end{array}$ & $\begin{array}{l}\text { Proportion } \\
\text { (95\% Cl) } \\
\text { High-risk group } \\
\text { Low-risk group }\end{array}$ & $\begin{array}{l}\text { Event rate } \\
\text { (95\% CI) } \\
\text { High-risk group } \\
\text { Low-risk group }\end{array}$ \\
\hline & Overall & 2 & & & $\begin{array}{l}\text { Death VTE major } \\
\text { bleeding }\end{array}$ & 3 months & $\begin{array}{l}10.2(6.9 \text { to } 14.7) \\
89.8(85.3 \text { to } 93.1)\end{array}$ & $\begin{array}{l}37.6(25.1 \text { to } 52) \\
6.7(4.7 \text { to } 9.6)\end{array}$ \\
\hline \multicolumn{9}{|l|}{$G P S \geq 5$} \\
\hline$(\text { Wicki et al 2000) })^{122}$ & Derivation & 1 & Retrospective & Not reported & $\begin{array}{l}\text { Death VTE major } \\
\text { bleeding }\end{array}$ & 3 months & $\begin{array}{l}3.7(2.0 \text { to } 6.8) \\
96.3(93.2 \text { to } 98.0)\end{array}$ & $\begin{array}{l}70.0(37.6 \text { to } 90.0) \\
7.8(5.1 \text { to } 11.7)\end{array}$ \\
\hline$(\text { Nendaz et al 2004) })^{97}$ & $\begin{array}{l}\text { External } \\
\text { validation }\end{array}$ & 1 & Retrospective & Unclear & $\begin{array}{l}\text { Death VTE major } \\
\text { bleeding }\end{array}$ & 3 months & $\begin{array}{l}2.5(1.0 \text { to } 5.9) \\
97.5(94.1 \text { to } 99.0)\end{array}$ & $\begin{array}{l}80.0(30.9 \text { to } 97.3) \\
7.7(4.7 \text { to } 12.4)\end{array}$ \\
\hline & Overall & 2 & & & $\begin{array}{l}\text { Death VTE major } \\
\text { bleeding }\end{array}$ & 3 months & $\begin{array}{l}3.3(2.0 \text { to } 5.4) \\
96.7(94.6 \text { to } 98.0)\end{array}$ & $\begin{array}{l}73.0(46.1 \text { to } 89.5) \\
7.7(5.6 \text { to } 10.6)\end{array}$ \\
\hline \multicolumn{9}{|l|}{$G P S=6$} \\
\hline$\left(\right.$ Wicki et al 2000) ${ }^{122}$ & Derivation & 1 & Retrospective & Not reported & $\begin{array}{l}\text { Death VTE major } \\
\text { bleeding }\end{array}$ & 3 months & $\begin{array}{l}1(0.4 \text { to } 3.4) \\
98.9(96.6 \text { to } 99.6)\end{array}$ & $\begin{array}{l}87.5(26.6 \text { to } 99.3) \\
9.1(6.1 \text { to } 13.2)\end{array}$ \\
\hline \multirow[t]{2}{*}{ (Nendaz et al 2004) $^{97}$} & $\begin{array}{l}\text { External } \\
\text { validation }\end{array}$ & 1 & Retrospective & Unclear & $\begin{array}{l}\text { Death VTE major } \\
\text { bleeding }\end{array}$ & 3 months & $\begin{array}{l}10.5(0.1 \text { to } 3.5) \\
99.5(96.5 \text { to } 99.9)\end{array}$ & $\begin{array}{l}\text { NA } \\
9.6(6.2 \text { to } 14.6)\end{array}$ \\
\hline & Overall & 2 & & & $\begin{array}{l}\text { Death VTE major } \\
\text { bleeding }\end{array}$ & 3 months & $\begin{array}{l}0.9(0.3 \text { to } 2.4) \\
99.1 \text { (97.6 to } 99.7)\end{array}$ & $\begin{array}{l}87.5 \text { (26.6 to } 99.3) \\
9.3 \text { (7.0 to } 12.3)\end{array}$ \\
\hline \multicolumn{9}{|l|}{$P E S I \geq \|$} \\
\hline (Aujesky et al 2007) $^{70}$ & $\begin{array}{l}\text { External } \\
\text { validation }\end{array}$ & 1 & Retrospective & $\begin{array}{l}\text { Both stable and } \\
\text { unstable }\end{array}$ & PE-related death & 3 months & $\begin{array}{l}79.5 \text { (76.8 to } 82) \\
20.5 \text { (18 to } 23.2)\end{array}$ & $\begin{array}{l}2.9(1.9 \text { to } 4.5) \\
0.3(0 \text { to } 4.2)\end{array}$ \\
\hline \multicolumn{9}{|l|}{$P E S I \geq I I I$} \\
\hline$($ Vanni et al 2011) & $\begin{array}{l}\text { External } \\
\text { validation }\end{array}$ & 1 & Retrospective & $\begin{array}{l}\text { Both stable and } \\
\text { unstable }\end{array}$ & PE-related death & In-hospital & $\begin{array}{l}68.7(64.3 \text { to } 72.7) \\
31.3(27.3 \text { to } 35.7)\end{array}$ & $\begin{array}{l}7.5(5.1 \text { to } 11) \\
0.7(0.1 \text { to } 4.7)\end{array}$ \\
\hline (Aujesky et al 2007) $^{70}$ & $\begin{array}{l}\text { External } \\
\text { validation }\end{array}$ & 1 & Retrospective & $\begin{array}{l}\text { Both stable and } \\
\text { unstable }\end{array}$ & PE-related death & 3 months & $\begin{array}{l}52.6(49.3 \text { to } 55.9) \\
47.4(44.1 \text { to } 50.7)\end{array}$ & $\begin{array}{l}3.8(2.4 \text { to } 6) \\
0.7(0.2 \text { to } 2.2)\end{array}$ \\
\hline \multicolumn{9}{|l|}{$P E S I \geq I V$} \\
\hline$($ Choi et al 2014) & $\begin{array}{l}\text { External } \\
\text { validation }\end{array}$ & 1 & Retrospective & $\begin{array}{l}\text { Both stable and } \\
\text { unstable }\end{array}$ & Adverse outcome & In-hospital & $\begin{array}{l}18(15.3 \text { to } 21.2) \\
82(78.8 \text { to } 84.7)\end{array}$ & $\begin{array}{l}24.8(17.8 \text { to } 33.4) \\
7.3(5.4 \text { to } 9.9)\end{array}$ \\
\hline (Aujesky et al 2007) & $\begin{array}{l}\text { External } \\
\text { validation }\end{array}$ & 1 & Retrospective & $\begin{array}{l}\text { Both stable and } \\
\text { unstable }\end{array}$ & PE-related death & 3 months & $\begin{array}{l}25 \text { (22.3 to } 28) \\
75 \text { (72 to } 77.7)\end{array}$ & $\begin{array}{l}6.7(4.1 \text { to } 10.8) \\
0.9(0.4 \text { to } 2)\end{array}$ \\
\hline \multicolumn{9}{|l|}{$P E S I=V$} \\
\hline (Aujesky et al 2007) $^{70}$ & $\begin{array}{l}\text { External } \\
\text { validation }\end{array}$ & 1 & Retrospective & $\begin{array}{l}\text { Both stable and } \\
\text { unstable }\end{array}$ & PE-related death & 3 months & $\begin{array}{l}10.3(8.5 \text { to } 12.5) \\
89.7(87.5 \text { to } 91.5)\end{array}$ & $\begin{array}{l}7.5 \text { (3.6 to } 15) \\
1.7(1 \text { to } 2.9)\end{array}$ \\
\hline \multicolumn{9}{|c|}{$P E S I \geq I V$ and other prognostic factors* } \\
\hline$(\text { Choi et al 2014) })^{77}$ & $\begin{array}{l}\text { External } \\
\text { validation }\end{array}$ & 1 & Retrospective & $\begin{array}{l}\text { Both stable and } \\
\text { unstable }\end{array}$ & Adverse outcome & In-hospital & & \\
\hline \multirow[t]{2}{*}{ NT-proBNP $\geq 1136 \mathrm{pg} / \mathrm{mL}$} & & & & & & & 34.2 (29.7 to 39.0$)$ & 22.416 .1 to 30.2$)$ \\
\hline & & & & & & & $65.8(61.0$ to 70.3$)$ & $4.7(2.7$ to 8.0$)$ \\
\hline \multirow[t]{2}{*}{$\mathrm{cTnl} \geq 0.05 \mathrm{ng} / \mathrm{mL}$} & & & & & & & 39.1 (34.8 to 43.6$)$ & 21.6 (16.3 to 28.1$)$ \\
\hline & & & & & & & $60.9(56.4$ to 65.2$)$ & $5.2(3.2$ to 8.5$)$ \\
\hline
\end{tabular}




\begin{tabular}{|c|c|c|c|c|c|c|c|c|}
\hline Risk cut-off (author, year) & $\begin{array}{l}\text { Development } \\
\text { phase }\end{array}$ & $\begin{array}{l}\mathrm{N} \\
\text { studies }\end{array}$ & $\begin{array}{l}\text { Type of } \\
\text { study }\end{array}$ & $\begin{array}{l}\text { Haemodynamic } \\
\text { status }\end{array}$ & Outcome & $\begin{array}{l}\text { Time } \\
\text { point }\end{array}$ & $\begin{array}{l}\text { Proportion } \\
(95 \% \mathrm{Cl}) \\
\text { High-risk group } \\
\text { Low-risk group }\end{array}$ & $\begin{array}{l}\text { Event rate } \\
(95 \% \mathrm{Cl}) \\
\text { High-risk group } \\
\text { Low-risk group }\end{array}$ \\
\hline CT RV/LV diameter ratio $\geq 1$ & & & & & & & $\begin{array}{l}36.1(32.5 \text { to } 39.9) \\
63.9(60.1 \text { to } 67.5)\end{array}$ & $\begin{array}{l}20.1(15.4 \text { to } 25.7) \\
5.1(3.3 \text { to } 7.7)\end{array}$ \\
\hline$P E S I \geq I V — N T-p r o B N P \geq 1136 \mathrm{pg} / \mathrm{mL}$ & & & & & & & $\begin{array}{l}6.2(4.2 \text { to } 9.1) \\
93.8(90.9 \text { to } 95.8)\end{array}$ & $\begin{array}{l}50.0(31.0 \text { to } 69.0) \\
8.0(5.6 \text { to } 11.3)\end{array}$ \\
\hline$P E S I \geq \mid V-c T n l \geq 0.05 \mathrm{ng} / \mathrm{mL}$ & & & & & & & $\begin{array}{l}10.3(7.8 \text { to } 13.4) \\
89.7(86.6 \text { to } 92.2)\end{array}$ & $\begin{array}{l}41.7(28.7 \text { to } 55.9) \\
8.1 \text { (5.9 to } 11.1)\end{array}$ \\
\hline $\mathrm{PESI} \geq \mathrm{IV}-\mathrm{CT}$ RV/LV ratio $\geq 1$ & & & & & & & $\begin{array}{l}7.9(6.0 \text { to } 10.2) \\
92.1(89.8 \text { to } 94.0)\end{array}$ & $\begin{array}{l}43.1(30.4 \text { to } 56.9) \\
7.7(5.8 \text { to } 10.2)\end{array}$ \\
\hline $\mathrm{PESI} \geq \mid \mathrm{IV}-\mathrm{NT}$-proBNP—cTnl & & & & & & & $\begin{array}{l}4.6(2.9 \text { to } 7.3) \\
95.4(92.7 \text { to } 97.1)\end{array}$ & $\begin{array}{l}64.7(40.4 \text { to } 83.2) \\
8.2(5.8 \text { to } 11.6)\end{array}$ \\
\hline $\mathrm{PESI} \geq \mathrm{IV}-\mathrm{NT}$-proBNP—RV/LV & & & & & & & $\begin{array}{l}4.2(2.6 \text { to } 6.7) \\
95.8(93.3 \text { to } 97.4)\end{array}$ & $\begin{array}{l}62.5(37.7 \text { to } 82.1) \\
8.4(6.0 \text { to } 11.7)\end{array}$ \\
\hline $\mathrm{PESI} \geq \mathrm{IV}-\mathrm{cTnl}-\mathrm{RV} / \mathrm{LV}$ & & & & & & & $\begin{array}{l}6.0(4.2 \text { to } 8.6) \\
94.0(91.4 \text { to } 95.8)\end{array}$ & $\begin{array}{l}60.7(42.0 \text { to } 76.7) \\
8.5(6.2 \text { to } 11.5)\end{array}$ \\
\hline $\mathrm{PESI} \geq \mid \mathrm{IV}-\mathrm{NT}$-proBNP—cTnI- & & & & & & & $3.8(2.3$ to 6.3$)$ & 71.4 (43.9 to 88.9$)$ \\
\hline $\begin{array}{l}\mathrm{RV} / L \mathrm{~V} \\
P R E P\end{array}$ & & & & & & & 96.2 (93.7 to 97.7 ) & $8.5(6.0$ to 11.9$)$ \\
\hline$(\text { Sanchez et al 2010) })^{110}$ & Derivation & 1 & Prospective & $\begin{array}{l}\text { Both stable and } \\
\text { unstable }\end{array}$ & Death VTE & 30 days & & \\
\hline PREP-Clin $\geq$ II & & & & & & & $\begin{array}{l}37.3(33.2 \text { to } 41.5) \\
62.7(58.5 \text { to } 66.8)\end{array}$ & $\begin{array}{l}17.7(12.9 \text { to } 23.8) \\
1.9(0.8 \text { to } 4.1)\end{array}$ \\
\hline PREP-Clin $\geq$ III & & & & & & & $\begin{array}{l}7.2(5.2 \text { to } 9.8) \\
92.8(90.2 \text { to } 94.8)\end{array}$ & $\begin{array}{l}43.2(28.4 \text { to } 59.4) \\
5.4(3.7 \text { to } 7.9)\end{array}$ \\
\hline PREP-Clin $\geq \|$ IINP-RVD & & & & & & & $\begin{array}{l}34.8 \text { (30.8 to } 39) \\
65.2(61 \text { to } 69.2)\end{array}$ & $\begin{array}{l}18.4(13.4 \text { to } 24.8) \\
2.1 \text { (1 to } 4.3)\end{array}$ \\
\hline PREP-Clin $\geq I I I-B N P-R V D$ & & & & & & & $\begin{array}{l}5.6(3.9 \text { to } 8) \\
94.4 \text { (92 to } 96.1)\end{array}$ & $\begin{array}{l}44.8(28.1 \text { to } 62.8) \\
5.6 \text { (3.8 to } 8)\end{array}$ \\
\hline $\begin{array}{l}\text { Shock Index } \\
\text { (Toosi et al 2008) }^{117}\end{array}$ & $\begin{array}{l}\text { External } \\
\text { validation }\end{array}$ & 1 & Retrospective & Not reported & Adverse outcome & In-hospital & $\begin{array}{l}17.6(12.4 \text { to } 24.5) \\
82.4(75.5 \text { to } 87.6)\end{array}$ & $\begin{array}{l}25.9(12.9 \text { to } 45.3) \\
10.3(6.1 \text { to } 17)\end{array}$ \\
\hline$s P E S I \geq 1$ & & & & & & & & \\
\hline (Righini et al 2011) $^{106}$ & $\begin{array}{l}\text { External } \\
\text { validation }\end{array}$ & 1 & Retrospective & Unclear & PE-related death & 30 days & $\begin{array}{l}53.8(48.6 \text { to } 58.9) \\
46.2(41.1 \text { to } 51.4)\end{array}$ & $\begin{array}{l}3.1(1.4 \text { to } 6.8) \\
0.6(0.1 \text { to } 4.2)\end{array}$ \\
\hline$\left(\right.$ Spirk et al 2011) ${ }^{115}$ & $\begin{array}{l}\text { External } \\
\text { validation }\end{array}$ & 1 & Retrospective & $\begin{array}{l}\text { Both stable and } \\
\text { unstable }\end{array}$ & Death VTE & 30 days & $\begin{array}{l}70.8(65.7 \text { to } 75.4) \\
29.2(24.6 \text { to } 34.3)\end{array}$ & $\begin{array}{l}8.1(5.2 \text { to } 12.3) \\
1(0.1 \text { to } 7)\end{array}$ \\
\hline
\end{tabular}




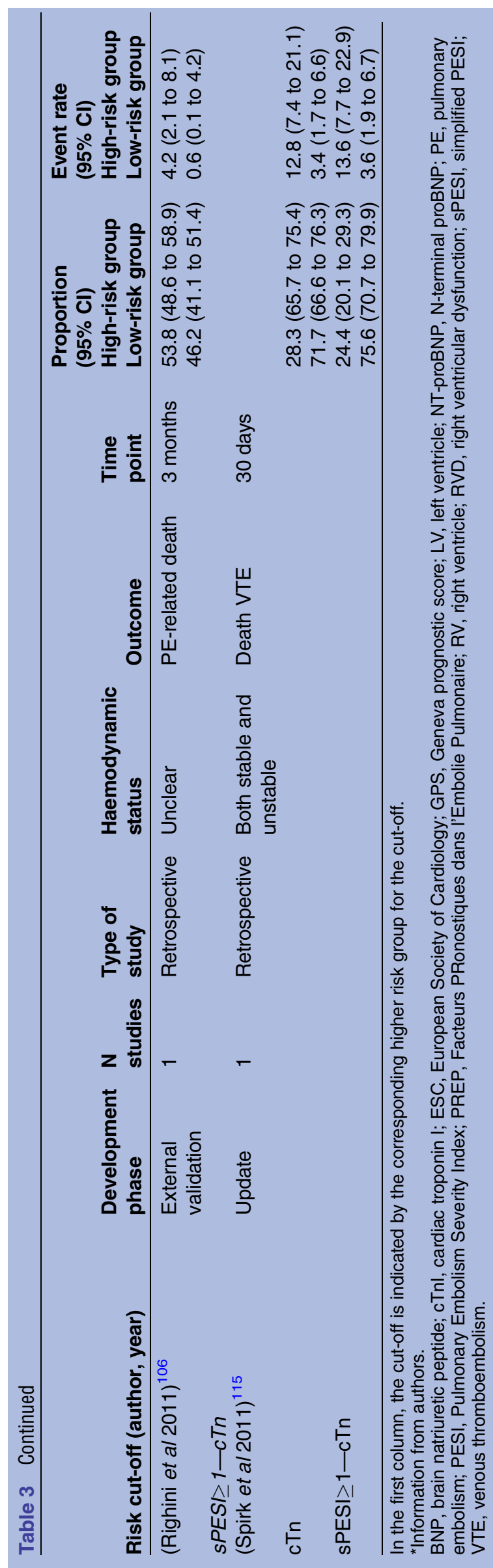

GRACE $\mathrm{PE}^{103}$ risk scores show $1.3 \%(0.1 \%$ to $17.1 \%)$ and $1.1 \%(0.1 \%$ to $15.1 \%)$ 30-day mortality rate, respectively, within the low-risk patient groups. Of note is a large 95\% CI for Geneva and GRACE scores due the small number of patients in the low-risk groups. Interestingly, the high event rates $(23-30 \%)$ in the highrisk groups of GRACE scores whatever the cut-offs with a high proportion $(49-81 \%)$ of patients in these risk groups. These models need to be validated in prospective studies with larger sample sizes in stable PE. Davies ${ }^{79}$ and Hestia ${ }^{125} 126$ checklists (table 5 and online supplementary table S2.5) show a high proportion of patients at low risk (42-55\%) with a small 3-month mortality rate: $1.9 \%(0.4 \%$ to $5.5 \%)$ and $1.2 \%(0.4 \%$ to $3.7 \%)$, respectively. These models need to be compared with PESI/sPESI models in impact studies.

\section{Incidence of events along the risk scale}

As expected, the event rates for different outcomes and time points increase along the risk scale. Tables 3-5 and online supplementary table $\mathrm{S} 4$ show how the predicted outcomes in the derivation samples compare with the observed outcomes in the validation samples (internal, external) at different cut-offs for GPS and PESI. Shifting the cut-off to a lower level or to a higher level provides more appropriate event rates in low-risk groups and in high-risk groups, respectively, but at the expense of a decrease in the proportion of patients within these risk groups. Thus, improvement in efficacy is associated with a decline in efficiency.

\section{Prognostic accuracy}

Summary estimates are displayed (see online supplementary tables S5 and S6) for different cut-offs as identified in studies to discriminate between low-risk and high-risk groups. They are provided only when at least four studies are identified for a specific cut-off, and a specific outcome and time point. The highest overall sensitivity estimates were obtained with the Prognostic Algorithm (4 studies) for predicting in-hospital mortality $(97 \%(96 \%$ to $98 \%))$ and 30-day mortality $(98 \%$ $(96 \%$ to $99 \%))$, followed by PESI (94\% (89\% to $97 \%)$ ) for 3-month mortality (6 external validation studies) and by sPESI $(93 \%$ (90\% to $95 \%))$ for 30-day (11 studies) and for 3-month mortality (10 external validation studies) (see online supplementary table S5). All results are consistent and similar in external validation studies. The same applies for LR negative estimates. The specificity is at best $54 \% \quad(46 \%$ to $62 \%)$ for PESI $\geq$ III cut-off for 3-month mortality. Shifting the cut-off along the risk scale provides higher values for sensitivity or for specificity (see online supplementary table S6). In figures 2 and 3, sROC plots showing test accuracy of the two most validated models at relevant cut-offs $\mathrm{PESI} \geq \mathrm{III}$ and sPESI $\geq 1$ associated with 30 -day all-cause death for all studies and for external validation studies are given separately. 
Table 4 PE-related death, adverse outcome (death, clinical deterioration or haemodynamic collapse), VTE, major bleeding and their combinations in 'stable' PE patient risk groups

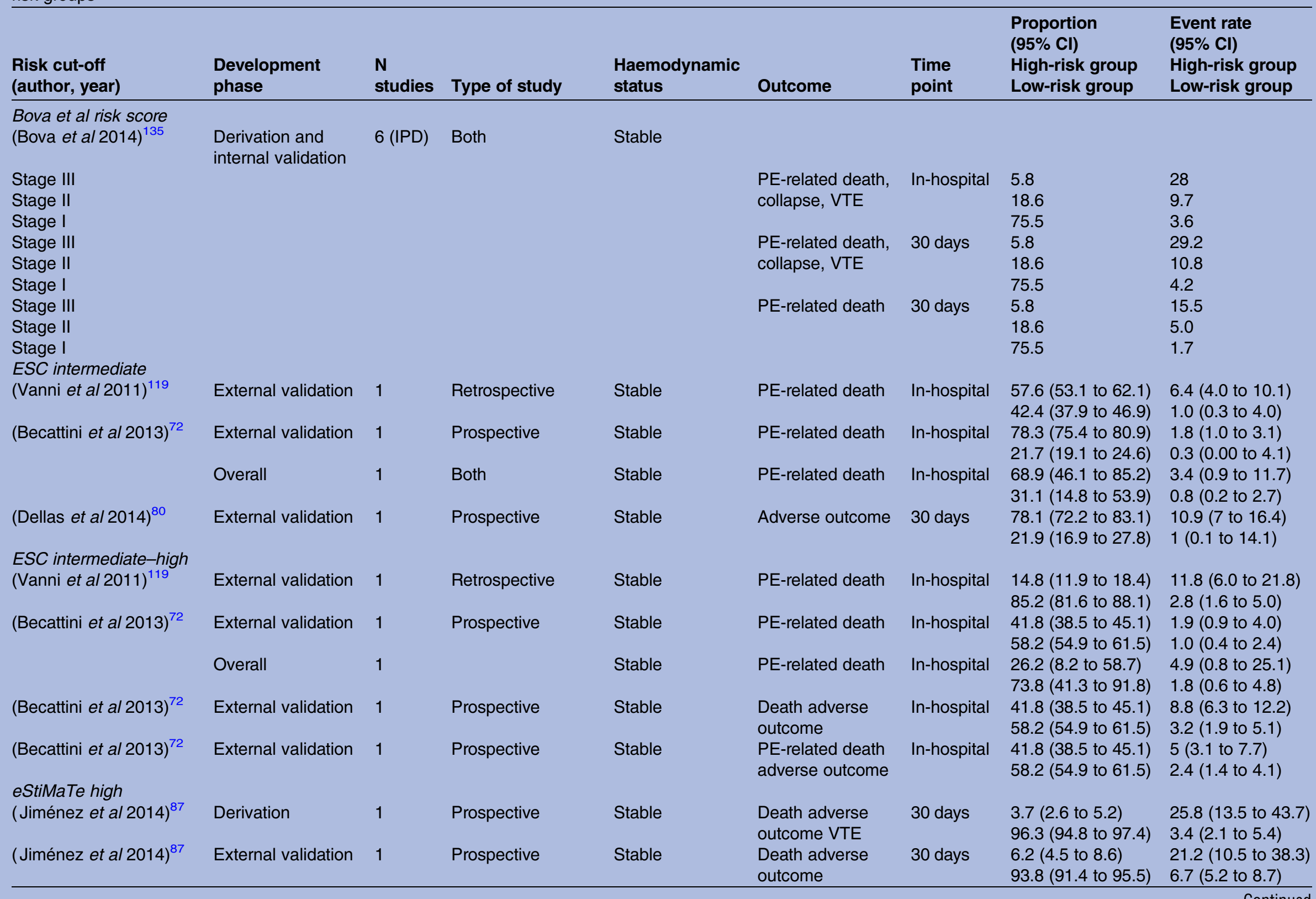




Time point

\section{Risk cut-off}

(author, year)

Development

(Jiménezet al 2014) ${ }^{87}$

Overal

eStiMaTe high-intermediate

(Jiménez et al 2014) $^{87} \quad$ Derivation

(Jiménez et al 2014) 87

External validation 1

(Jiménez et al 2014) $^{87}$

Overall

2

$F A S T=3$

(Dellas et al 2014) $^{80}$

External validation 1

External validation 1

(Bova et al 2009) ${ }^{74}$

Kostrubiec et al (NT-proBNP_cTnT)

(Kostrubiec et al

2005) ${ }^{90}$

Intermediate

Intermediate

Intermediate-high

Intermediate-high

$P E S I \geq I I$

(Sanchez et al 2013) $^{111}$ External validation

PESI $\geq I I I$

(Palmieri et al 2008) $^{104} \quad$ External validation

$\left(\right.$ Sanchez et al 2013) ${ }^{111} \quad$ External validation 1

$\left(\right.$ Vanni et al 2011) ${ }^{119} \quad$ External validation

$P E S I>I V$

$\left(\right.$ Sanchez et al 2013) ${ }^{111}$ External validation
Prospective

Prospective

\section{Prospective}

Prospective

Prospective

Stable

Stable

table

Stable

Prospective Stable

(1)

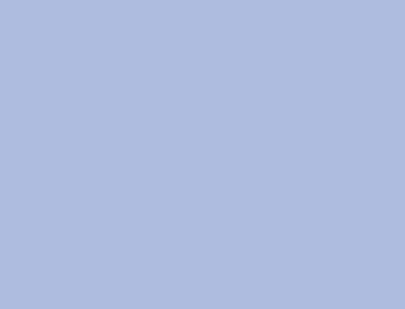

Retrospective Stable (for PESI)

Prospective

Retrospective (for PESI)

Retrospective

Stable

Stable

Stable

Retrospective Stable (for PESI)
Death

PE-related death

Death

PE-related death

Adverse outcome

Death adverse

outcome

Adverse outcome

PE-related death

Adverse outcome

Adverse outcome
Proportion

(95\% Cl) \\ (95\% Cl)}

Event rate

High-risk group Low-risk group

(95\% Cl)

4.8 (2.8 to 8$)$

95.2 (92 to 97.2 )

Low-risk group

23.5 (14.7 to 35.4$)$

30 days $\quad 74.5$ (71.5 to 77.3$) \quad 9.7$ (7.6 to 12.2$)$

25.5 (22.7 to 28.5$) \quad 0.9$ (0.2 to 3.6$)$

63.5 (59.3 to 37.5$) \quad 7.1$ (4.8 to 10.4 )

36.5 (32.5 to 40.7$) \quad 0.3$ (0 to 4$)$

69.3 (57.6 to 79$) \quad 8.6(6.5$ to 11.4$)$

30.7 (21 to 42.4 ) $\quad 0.7$ (0.2 to 2.4$)$

28.4 (23.4 to 34.1$) \quad 22.1$ (14.2 to 32.7$)$ 71.6 (65.9 to 76.6$) \quad 1.5(0.5$ to 4.7$)$

$18.9(14.1$ to 24.9$) \quad 2.6(0.4$ to 16.5$)$ 81.1 (75.1 to 85.9$) \quad 0.3(0.0$ to 4.7$)$

30 days $\quad 72.0(62.4$ to 79.9$) \quad 20.8(13.0$ to 31.7$)$ 28.0 (20.1 to 37.6$) \quad 1.7(0.1$ to 22.3$)$

69.9 (59.8 to 78.3$) \quad 12.3$ (6.3 to 22.7$)$

30.1 (21.7 to 40.2$) \quad 1.7(0.1$ to 22.3$)$

18.0 (11.6 to 26.8 ) 50.0 (28.4 to 71.6 )

82.0 (73.2 to 88.4$) \quad 7.3$ (3.3 to 15.3)

16.1 (1.0 to 25.0$) \quad 40.0(19.2$ to 65.2$)$

83.9 (75.0 to 90.0$) \quad 2.6$ (0.6 to 9.7$)$

75.2 (71.4 to 78.7$) \quad 6(4.1$ to 8.8$)$

24.8 (21.3 to 28.6$) \quad 0.8$ (0 to 5.2$)$

n-hospital $\quad 69.7$ (59.4 to 78.3$) \quad 53.2(40.9$ to 65.2$)$

30.3 (21.7 to 40.6$) \quad 11.1$ (3.6 to 29.3)

37.8 (33.8 to 42$) \quad 9(5.7$ to 13.8$)$

$\begin{array}{lll} & 62.2(58 \text { to } 66.2) & 2.1(1 \text { to } 4.4) \\ \text { n-hospital } & 67(62.3 \text { to } 71.3) & 6.1(3.8 \text { to } 9.5)\end{array}$

33 (28.7 to 37.7$) \quad 0.7$ (0.1 to 5$)$

0 days

17.2 (14.2 to 20.7$) \quad 8.8$ (4.5 to 16.6$)$ 82.8 (79.3 to 85.8$) \quad 3.9$ (2.4 to 6.2$)$ 


\begin{tabular}{|c|c|c|c|c|c|c|c|c|}
\hline $\begin{array}{l}\text { Risk cut-off } \\
\text { (author, year) }\end{array}$ & $\begin{array}{l}\text { Development } \\
\text { phase }\end{array}$ & $\begin{array}{l}\mathrm{N} \\
\text { studies }\end{array}$ & Type of study & $\begin{array}{l}\text { Haemodynamic } \\
\text { status }\end{array}$ & Outcome & $\begin{array}{l}\text { Time } \\
\text { point }\end{array}$ & $\begin{array}{l}\text { Proportion } \\
(\mathbf{9 5 \%} \mathrm{Cl}) \\
\text { High-risk group } \\
\text { Low-risk group }\end{array}$ & $\begin{array}{l}\text { Event rate } \\
(\mathbf{9 5 \%} \mathrm{Cl}) \\
\text { High-risk group } \\
\text { Low-risk group }\end{array}$ \\
\hline $\begin{array}{l}\text { PESI=V } \\
(\text { Sanchez et al 2013) })^{111}\end{array}$ & External validation & 1 & $\begin{array}{l}\text { Retrospective } \\
\text { (for PESI) }\end{array}$ & Stable & Adverse outcome & 30 days & $\begin{array}{l}4(2.6 \text { to } 6) \\
96 \text { (94 to } 97.4)\end{array}$ & $\begin{array}{l}14.3(4.7 \text { to } 36.1) \\
4.3(2.9 \text { to } 6.5)\end{array}$ \\
\hline $\begin{array}{l}\text { PESI+biomarkers } \\
(\text { Sanchez et al 2013) })^{111}\end{array}$ & External validation & 1 & $\begin{array}{l}\text { Retrospective } \\
\text { (for PESI) }\end{array}$ & Stable & Adverse outcome & 30 days & & \\
\hline PESI I-II—BNP & & & & & & & $\begin{array}{l}32.7(27.8 \text { to } 38.0) \\
67.3(62.0 \text { to } 72.2)\end{array}$ & $\begin{array}{l}4.7(2.0 \text { to } 10.8) \\
0.9(0.2 \text { to } 3.6)\end{array}$ \\
\hline PESI I-II—cTnl & & & & & & & $\begin{array}{l}13.7(10.3 \text { to } 17.9) \\
86.3(82.1 \text { to } 89.7)\end{array}$ & $\begin{array}{l}9.1(3.5 \text { to } 21.8) \\
1.1(0.3 \text { to } 3.3)\end{array}$ \\
\hline PESI I-II-TTE-RVD & & & & & & & $\begin{array}{l}12.3(9.0 \text { to } 16.5) \\
87.7(83.5 \text { to } 91.0)\end{array}$ & $\begin{array}{l}10.8(4.1 \text { to } 25.5) \\
1.1(0.4 \text { to } 3.5)\end{array}$ \\
\hline PESI III-IV—BNP & & & & & & & $\begin{array}{l}56.3(48.8 \text { to } 63.4) \\
43.8(36.6 \text { to } 51.2)\end{array}$ & $\begin{array}{l}10.1(5.5 \text { to } 17.8) \\
6.5(2.7 \text { to } 14.7)\end{array}$ \\
\hline PESI III-IV—cTnI & & & & & & & $\begin{array}{l}24.0(18.2 \text { to } 30.9) \\
76.0(69.1 \text { to } 81.8)\end{array}$ & $\begin{array}{l}16.7(8.2 \text { to } 31.0) \\
5.3(2.5 \text { to } 10.6)\end{array}$ \\
\hline PESI III-IV-TTE-RVD & & & & & & & $\begin{array}{l}22.8 \text { (17.0 to } 29.9) \\
77.2(70.1 \text { to } 83.0)\end{array}$ & $\begin{array}{l}10.8(4.1 \text { to } 25.5) \\
8.8(4.9 \text { to } 15.2)\end{array}$ \\
\hline PESI V—BNP & & & & & & & $\begin{array}{l}76.2(54.0 \text { to } 89.7) \\
23.8(10.3 \text { to } 46.0)\end{array}$ & $\begin{array}{l}18.8(6.2 \text { to } 44.7) \\
8.3(0.5 \text { to } 62.2)\end{array}$ \\
\hline PESI V—cTnl & & & & & & & $\begin{array}{l}30.0(14.1 \text { to } 52.7) \\
70.0(47.3 \text { to } 85.9)\end{array}$ & $\begin{array}{l}16.7(2.3 \text { to } 63.1) \\
14.3(3.6 \text { to } 42.7)\end{array}$ \\
\hline PESI V-TTE-RVD & & & & & & & $\begin{array}{l}23.8(10.3 \text { to } 46.0) \\
76.2(54.0 \text { to } 89.7)\end{array}$ & $\begin{array}{l}20.0 \text { (2.7 to } 69.1) \\
12.5(3.1 \text { to } 38.6)\end{array}$ \\
\hline $\begin{array}{l}\text { PESI+biomarkers } \\
\text { (Jimenez et al 2011) }^{86}\end{array}$ & Update & 1 & $\begin{array}{l}\text { Unclear } \\
\text { Prospective }\end{array}$ & Stable & PE-related death & 30 days & & \\
\hline cTnl & & & & & & & $\begin{array}{l}32.1(28.5 \text { to } 36.0) \\
67.9(64.0 \text { to } 71.5)\end{array}$ & $\begin{array}{l}10.5(6.9 \text { to } 15.8) \\
4.2(2.7 \text { to } 6.7)\end{array}$ \\
\hline TTE-RVD & & & & & & & $\begin{array}{l}20.3(17.3 \text { to } 23.7) \\
79.7(76.3 \text { to } 82.7)\end{array}$ & $\begin{array}{l}11.7(7.0 \text { to } 18.7) \\
4.9(3.3 \text { to } 7.2)\end{array}$ \\
\hline US-DVT & & & & & & & $\begin{array}{l}38.6(34.7 \text { to } 42.6) \\
61.4(57.4 \text { to } 65.3)\end{array}$ & $\begin{array}{l}9.6(6.4 \text { to } 14.2) \\
4.1(2.5 \text { to } 6.7)\end{array}$ \\
\hline TTE-RVD—cTnl & & & & & & & $\begin{array}{l}10.0(7.8 \text { to } 12.7) \\
90.0(87.3 \text { to } 92.2)\end{array}$ & $\begin{array}{l}15.3(8.1 \text { to } 26.8) \\
5.3(3.7 \text { to } 7.5)\end{array}$ \\
\hline $\begin{array}{l}\mathrm{PESI} \geq \mathrm{IV}-\mathrm{TTE}-\mathrm{RVD}- \\
\mathrm{cTnl}\end{array}$ & & & & & & & $\begin{array}{l}12.7(9.0 \text { to } 17.7) \\
87.3(82.3 \text { to } 91.0)\end{array}$ & $\begin{array}{l}20.7(9.6 \text { to } 39.0) \\
8.0(5.0 \text { to } 12.7)\end{array}$ \\
\hline cTnI-US-DVT & & & & & & & $\begin{array}{l}13.9(11.3 \text { to } 16.9) \\
86.1(83.1 \text { to } 88.7)\end{array}$ & $\begin{array}{l}17.1(10.4 \text { to } 26.8) \\
4.5 \text { (3.0 to } 6.7)\end{array}$ \\
\hline
\end{tabular}




\section{Table 4 Continued}

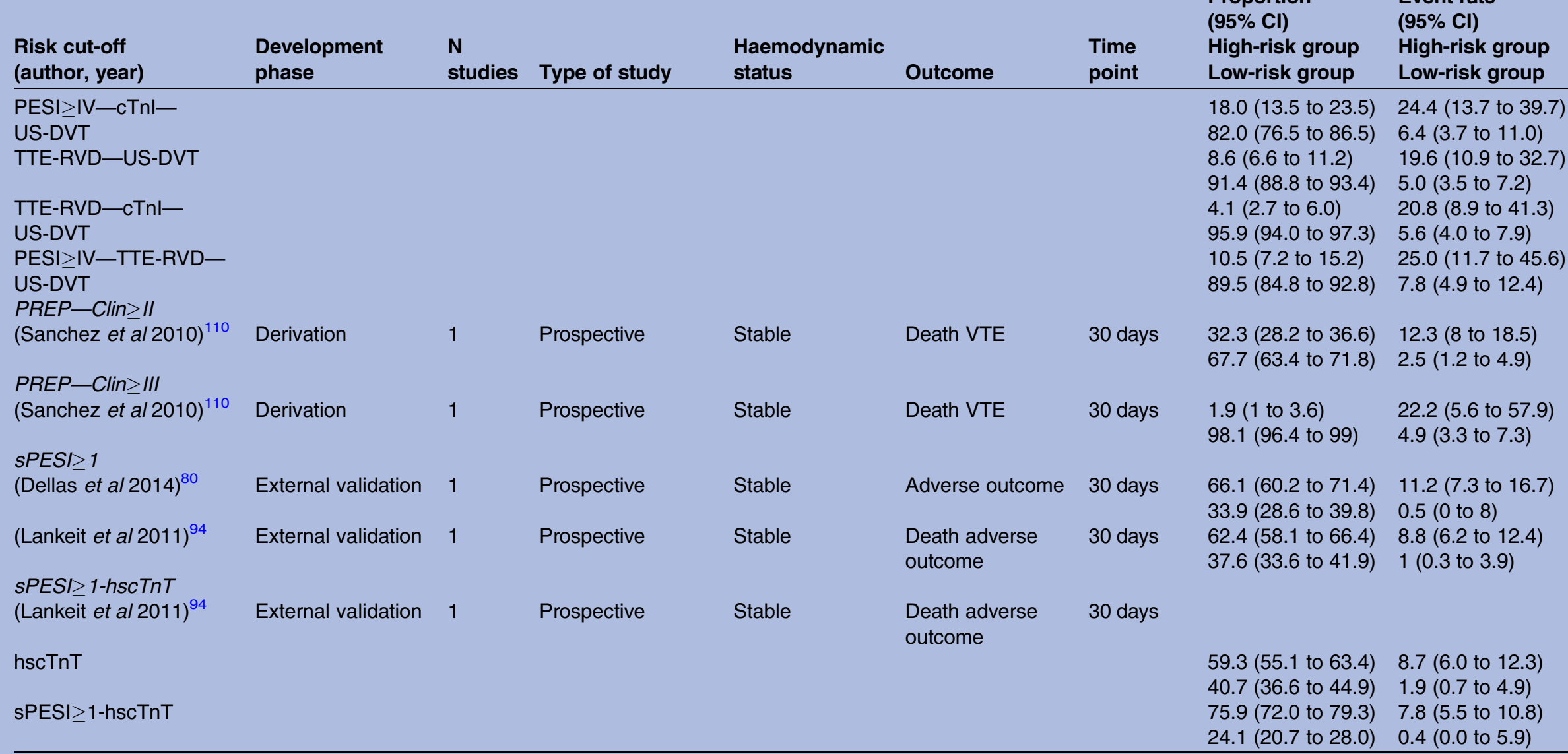

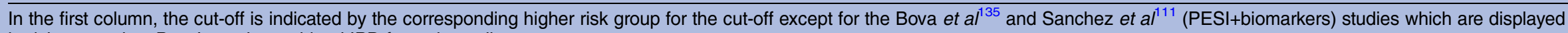
in risk categories. Bova's study combined IPD from six studies.

BNP, brain natriuretic peptide; cTnl, cardiac troponin I; cTnT, cardiac troponin T; DVT, deep vein thrombosis; GPS, Geneva prognostic score; hscTnT, high-sensitive cardiac troponin T; IPD,

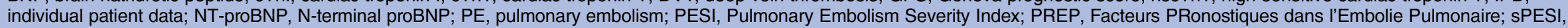
simplified PESI; TTE-RVD, transthoracic echocardiography-right ventricular dysfunction; US-DVT, ultrasound-detected DVT; VTE, venous thromboembolism. 
Table 5 Studies reporting on derivation and external validation of models originally not specific to the prognosis or the domain of PE (type 2 model studies), and studies reporting on hospital criteria checklists (type 3 model studies)

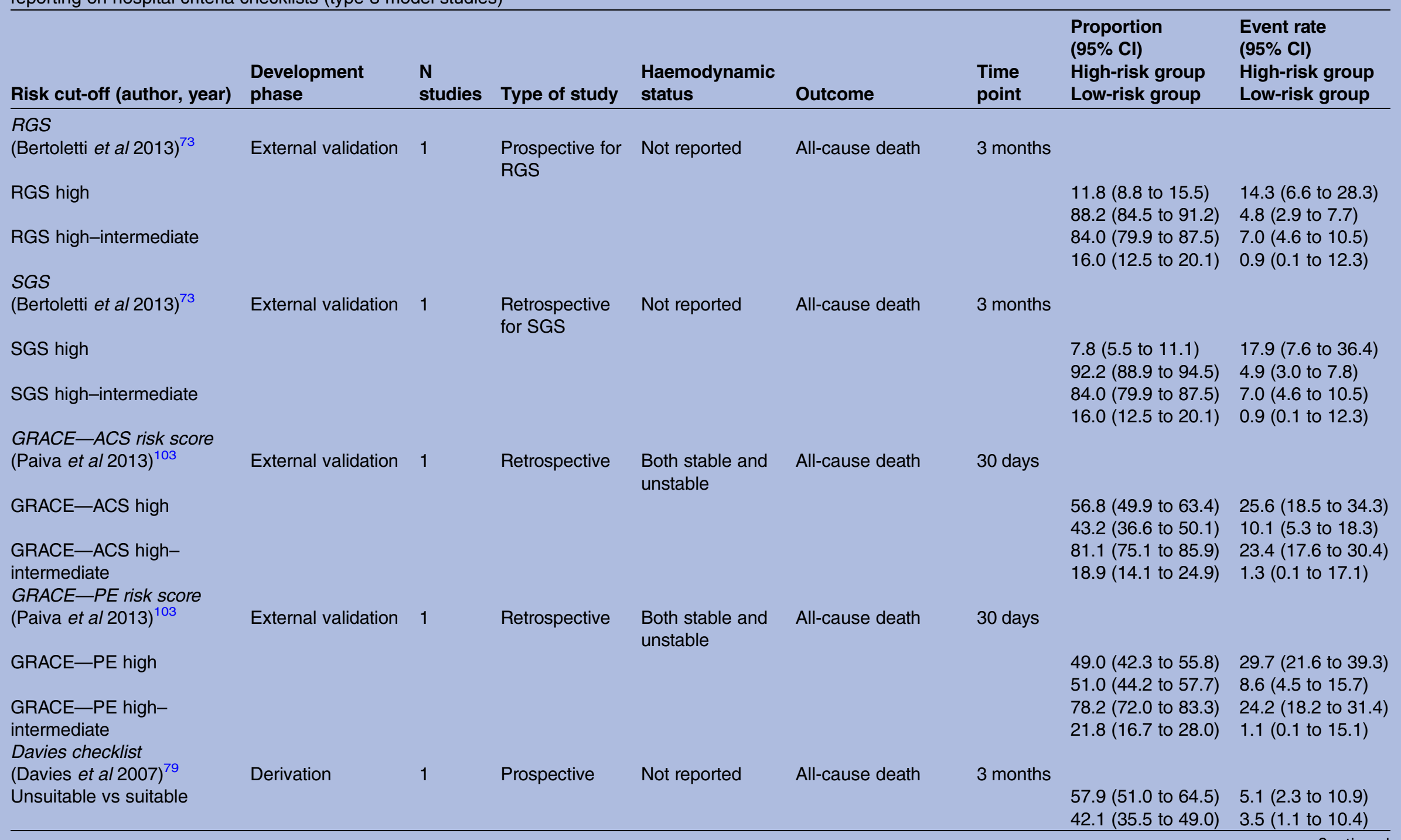

Continued 
Table 5 Continued

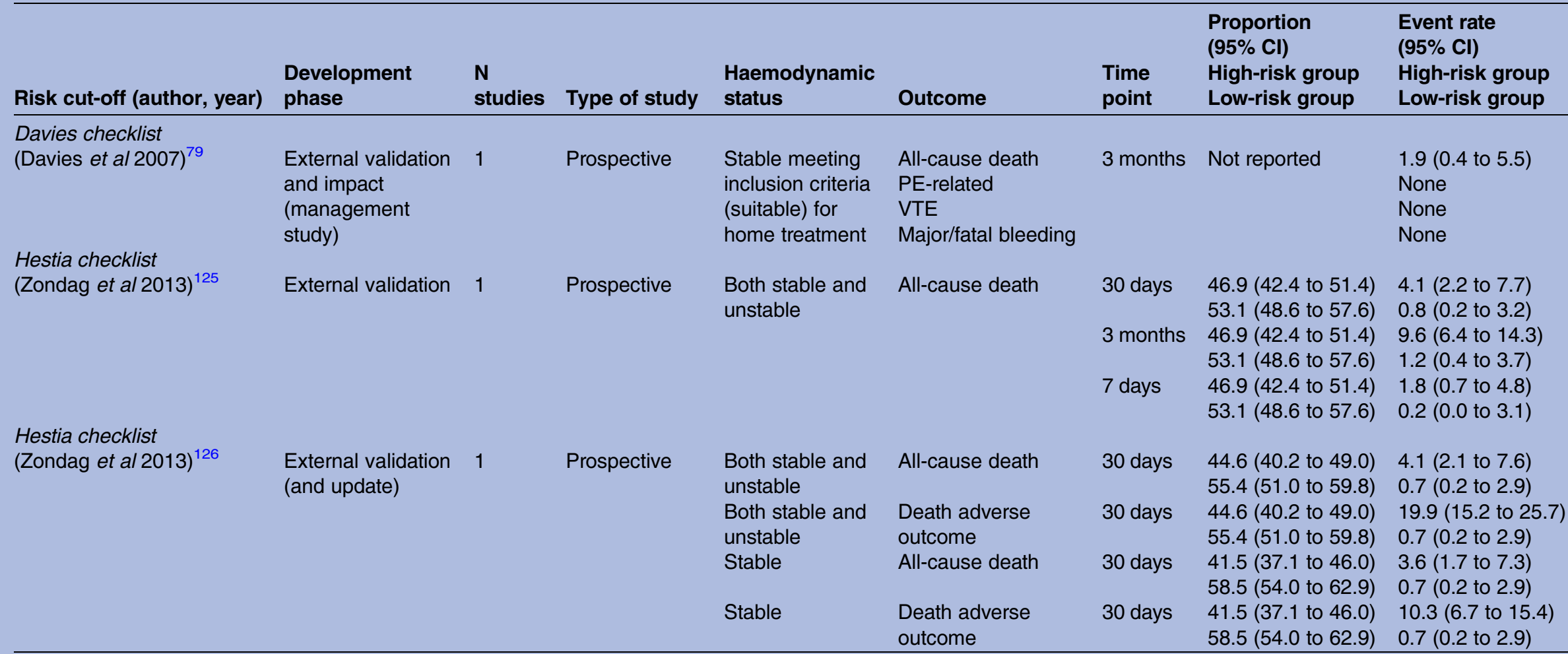

ACS, acute coronary syndrome; GRACE, Global Registry of Acute Coronary Events; PE, pulmonary embolism; RGS, revised Geneva score; SGS, simplified Geneva score; VTE, venous thromboembolism. 

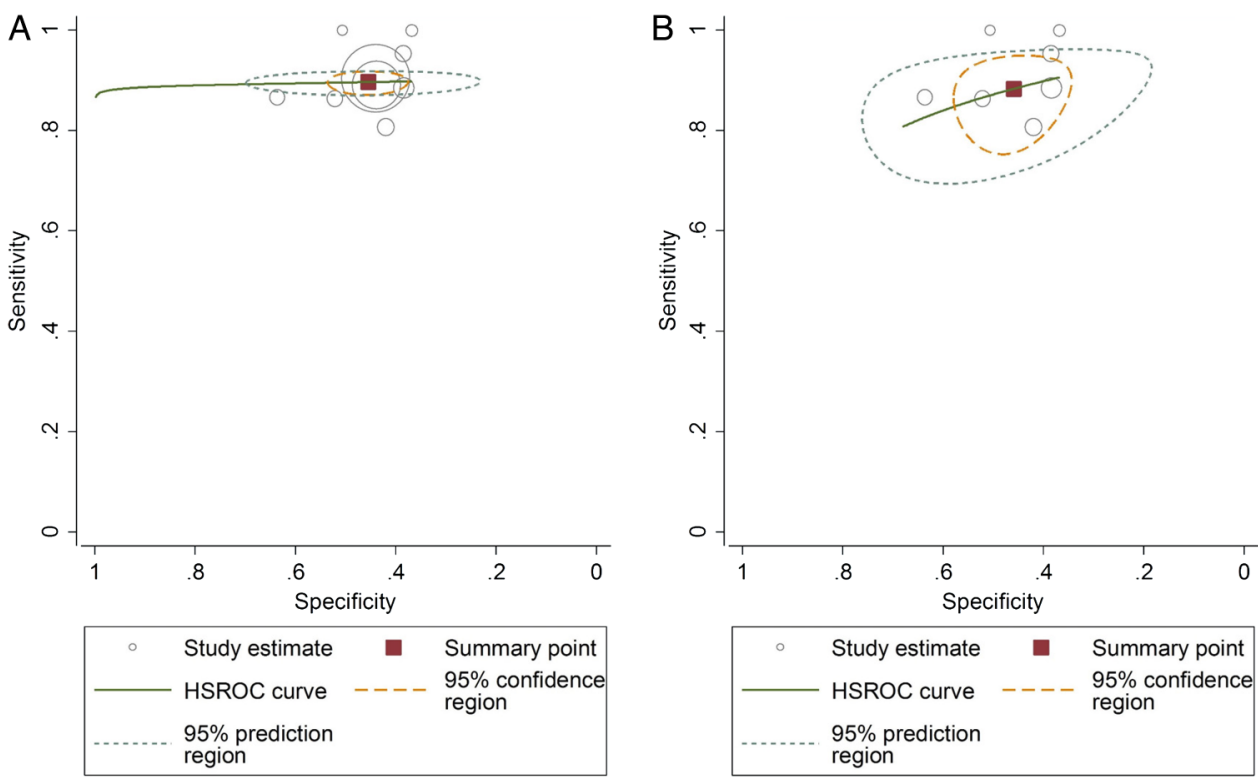

Figure 2 sROC plots showing test accuracy of PESI $\geq$ III cut-off associated with 30-day all-cause death: all studies (A) and external validation studies (B). HSROC, hierarchical summary receiver operating characteristic; PESI, Pulmonary Embolism Severity Index; sROC, summary receiver operating characteristic.

\section{Model updating}

For better identification of lower and higher risk groups, some studies assessed the effect on outcomes of adding one or more prognostic variables to an existing model. There is increasing evidence about the greater effectiveness of these 'new models', even though the existing ones such as PESI, sPESI and PREP are already highly effective.

In the study of Moores, the addition of non-elevated cTnI to low-risk PESI did not improve the negative predictive value compared with either test alone. ${ }^{96}$ In the Lankeit study, ${ }^{94}$ the combination of a negative high-

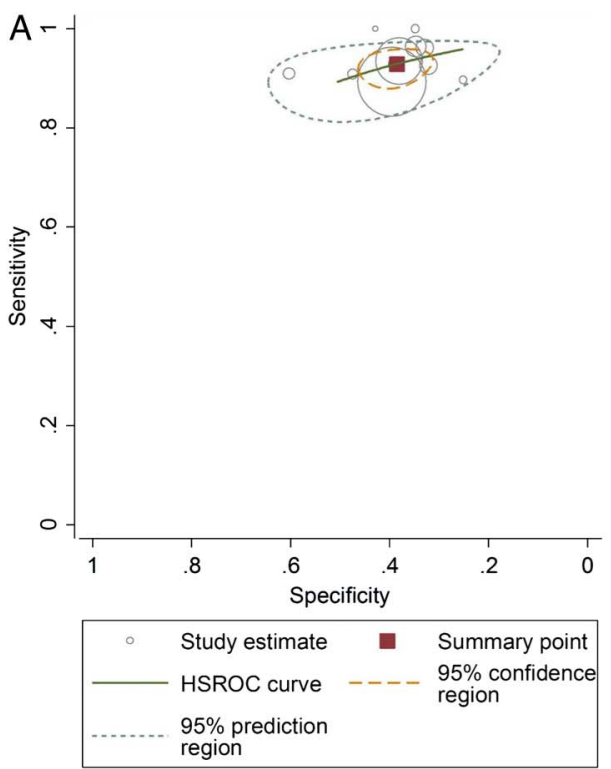

sensitive cTnT (hscTnT $<14 \mathrm{pg} / \mathrm{mL})$ and a sPESI value of 0 at baseline improved risk classification and reduced the risk of mortality. The same applies for the combination of NT-proBNP $(<600 \mathrm{pg} / \mathrm{mL})$ and low-risk sPESI. ${ }^{95}$ In the study of Ozsu, hscTnT combined with sPESI provided better predictive information than cTnT. ${ }^{101}$ Adding cTn to the PESI ${ }^{113}$ and the SPESI $^{115}$ models resulted in a higher area under the curve (AUC) value with no additive value for Ddimer to PESI and cTn. ${ }^{113}$ To sum up, there is an increased value in identifying lower risk patients by adding NT-proBNP and hscTnT to PESI or sPESI.

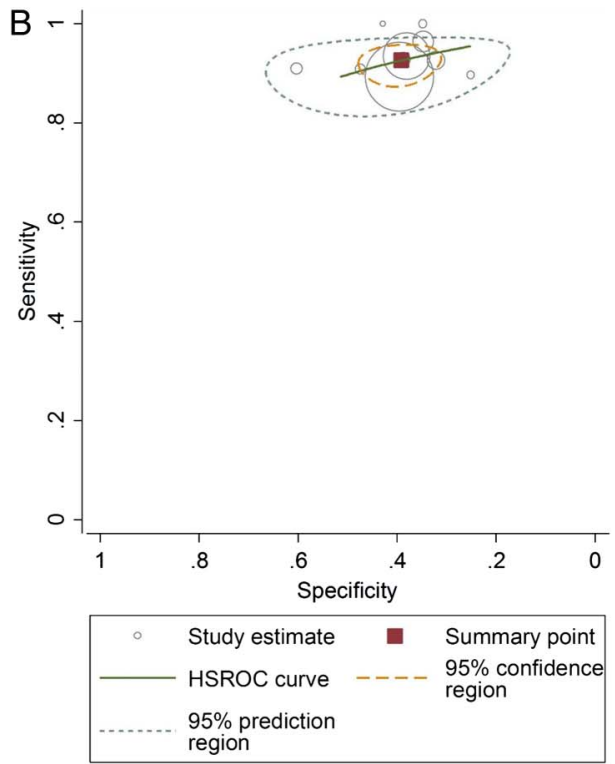

Figure 3 sROC plots showing test accuracy of SPESI $\geq 1$ cut-off associated with 30-day all-cause death: all studies (A) and external validation studies (B). HSROC, hierarchical summary receiver operating characteristic; PESI, Pulmonary Embolism Severity Index; SROC, summary receiver operating characteristic. 
Other update studies tried to improve the identification of high-risk patients. Adding BNP and TTE-RVD to the PREP clinical model resulted in a significant difference in AUC. ${ }^{110}$ A significant increase in 'NRI: Net Reclassification Improvement', as defined by Pencina $e t$ $a l,{ }^{142}$ was obtained in the original study which updated PREP model by adding BNP and TTE-RVD to the clinical model. ${ }^{110}$ Using the PREP cohort in patients with normotensive PE, Sanchez et al showed that biomarkers (cTnI, BNP) and echocardiography provided additional prognostic information to PESI. ${ }^{11}$ In the Palmieri study ${ }^{104}$ which included highly selected 'non-massive central PE', increased cTnI contributed to identifying patients with increased risk of development of haemodynamic instability, which was independent of, and in addition, to PESI. Novel models ${ }^{80} 8792135$ specifically developed for patients with normotensive PE and integrating biomarkers (cTn, NT-proBNP, heart-type fatty acid-binding protein (H-FABP)), CT or TTE-RVD and US-detected DVT with clinical variables (SBP, HR) or with sPESI, showed a high ability to identify patients at lower risk as well as at higher risk of early death or adverse outcome at the expense of a lower proportion of patients in these risk groups (tables 3 and 4).

\section{Tests of heterogeneity, investigation for publication bias, subgroup analysis and sensitivity analysis}

Results of tests for heterogeneity using Cochran's Q test and Higghins $\mathrm{I}^{2}$ statistic, and results of subgroup analyses show major problems of heterogeneity. Comparing results between studies reporting on 30-day all-cause death for PESI optimal cut-offs (PESI $\geq$ III,, $\mathrm{PESI} \geq 1$ ), all conditions for comparison being optimal (all studies are retrospective and external validation studies, and include 'both stable and unstable' patients with PE), we found important between-study heterogeneity (for instance for PESI: $Q$ value $=39.69$, df $5, \mathrm{p}=0.000, \mathrm{I}^{2}=87$ ) that might be related to only patient selection in studies. A high proportion of patients at low risk in study population (or a lower proportion of patients at high risk) results in less event rates in the population sample and less event rates within risk groups as shown on forest plots (see online supplementary figures S7-S12). Heterogeneity $\left(\mathrm{I}^{2}>50 \%\right)$ was observed in most of the analyses for 30-day all-cause death with $\mathrm{PESI} \geq \mathrm{III}$ and sPESI. At best $\mathrm{I}^{2}$ test for heterogeneity was $39 \%$ (all studies combined) and 50\% (external validation studies only) in low-risk PESI group.

Findings from the investigation for publication bias using the 'Funnel Plot' of SE and precision $(=1 / \mathrm{SE})$ by Logit event rate (with comparison of plots with observed studies against plots with observed and imputed studies), and the Egger's test of regression intercept show no evidence of publication bias except for studies using PESI $\geq \mathrm{III}$ and PESI=V cut-offs for 30-day all-cause death (see online supplementary figures S13.1 and S13.2).

\section{Model impact}

The clinical utility of a model is assessed by its effect on clinical decision-making and subsequent patient outcomes. However, few such studies have been performed of the PE models (see online supplementary table S2.4).

The safety of treating patients with low-risk PE as outpatients was examined in two management studies ${ }^{66} 128$ and in two randomised trials. ${ }^{71} 100$ The first management study $^{128}$ was a feasibility study among low-risk patients based on the GPS model in a very small number of patients. It showed the use of the GPS model to be safe. In the other one-arm management study, patients with stable PE with NT-proBNP $<500 \mathrm{pg} / \mathrm{mL}$ were treated at home. Seven $(4.6 \%)$ patients were readmitted within the first 10 days, but there were no deaths, no VTE events and no clinically relevant or major bleeding at 3-month follow-up. The first of the two randomised trials ${ }^{100} \mathrm{did}$ not demonstrate the clinical utility of Uresandi's model ${ }^{118}$ for outpatient management. The rate of shortterm mortality was unexpectedly high in both management groups, as was the rate of VTE events and major bleeding. The second randomised trial ${ }^{71}$ was a noninferiority study in highly selected patients with low-risk PE. It showed that outpatient care based on the PESI model can safely and effectively be used in place of inpatient care: $1(0.6 \%)$ death in each group, with 1 $(0.6 \%)$ VTE and $2(1.2 \%)$ major bleeding events in the outpatient group at a 3-month follow-up. Owing to other eligibility criteria for outpatient management and study design, only $56 \%$ (152/271) with low NT-proBNP level, ${ }^{66}$ $13 \%(132 / 1016)$ with low-risk Uresandi's model, ${ }^{100} 18 \%$ $(43 / 244)$ with low-risk GPS $^{128}$ and $44 \%(344 / 783)$ with PESI I-II ${ }^{71}$ could be treated as outpatients.

The PEITHO study ${ }^{132}$ randomised patients with normotensive PE at 'intermediate-high' risk (with RVD and myocardial injury) to receive tenecteplase (fibrinolytics) or placebo. Death or hemodynamic decompensation occurred in $13 / 506$ patients $(2.6 \%)$ in the tenecteplase group as compared with $28 / 499(5.6 \%)$ in the placebo group. Fibrinolytic therapy did not prevent in-hospital death and increased the risk of major haemorrhage and stroke. Models are less specific for predicting poor outcome in normotensive high-risk patients and might benefit from combining prognostic variables for better selection of patients, in particular those at risk of death from PE, as long as patients who are likely to respond to therapy are identified.

Finally, risk stratification was found to be frequently performed in patients admitted with acute PE and found to be stable during a 5 -year period. ${ }^{133}$ Its use was associated with assignment to higher levels of care and more intense treatment, but did not improve the outcome. ${ }^{133}$

\section{DISCUSSION}

\section{Summary of main results}

This systematic review identified 17 prognostic models in acute PE and other types of models that were not 
originally specific to PE or exclusively to its prognosis. Eight models were validated or updated and three were assessed in impact studies. Overall, PESI and sPESI are the models that have been most widely validated and updated, and PESI is the only one that has been assessed and found useful in a randomised trial for treating patients with low-risk PE as outpatients (level 1 of hierarchy of evidence according to McGinn et $a l^{143}$ ). As expected, the event rates for different outcomes and time points increase along the risk scale in PESI model. The attempt to simplify PESI is attractive and successful in validation studies, but needs to be evaluated in impact studies. Agreement between the simplified PESI and the original PESI is fair. ${ }^{106}$ PESI and sPESI models are now included in the risk stratification of patients with PE in the 2014 ESC guidelines. ${ }^{3}$ This new strategy needs to be validated and compared to the existing models. Other prognostic models have shown improvement in identifying low-risk and high-risk groups either on their own (algorithm for the low risk-Shock Index, 2008 ESC high, PREP-Clin III, PESI $\geq$ IV, PESI V, eStiMaTe high, FAST 3, Bova stage III for the high risk), or by the addition of one or more clinical, biological and imaging-based markers of RVD and myocardial injury to the existing models or by incorporating these markers into new models (NT-proBNP and hscTn for the low risk-SBP, BNP, cTN, H-FABP, venous US and imaging-based RVD for the high risk). Large validation and impact studies are needed to assess these new and updated models.

\section{Overall completeness and applicability of evidence}

Most of the models are effective and provide a low event rate in low-risk groups, and appear reproducible and robust. However, using the model for identifying the low-risk groups may not be worthwhile if the aim is to make a choice to send the patients home; because the patients might still have an unacceptable high risk of a serious adverse outcome. It is important to define the incidence limit for a specific outcome, which should be clinically relevant and if models go beyond this they should not be viewed as of high performance. In agreement with the review of Vinson et al, ${ }^{144}$ careful selection is needed for low-risk patients with acute PE who will be managed as outpatients. Broad implementation of this management strategy is controversial and varies across countries and across organisation of patient care and patient pathways. Furthermore, decisions about management might be modified by the availability of new oral anticoagulants being studied in large-scale clinical trials. ${ }^{144}$ Hospital checklist criteria ${ }^{79} 125$ should also be helpful for patient selection and seem to be competitive with prognostic models.

Differences in predictive performance of the models may be due to differences in prognostic criteria and threshold for risk groups regardless of study design, development phase, population, outcome and time point. In two model construction studies ${ }^{68} 69$ using the same cohort and the same outcome, a change in criteria and threshold resulted in change of risk group proportions and event rates within these risk groups. Shifting the cut-off to reduce the incidence of events in the low-risk group led to a smaller proportion of patients in the low-risk group, and selecting patients with lower risk PE makes the model more effective but less efficient. This also applies to the high-risk patient groups: the greater the proportion of patients classified as high risk, the lower the incidence of outcomes in this group and vice versa. Adding biomarker data may help to identify higher or lower risk patients, but the findings on the additive value of biomarkers are inconsistent across studies. This may be explained by the higher predictive performance of some models, heterogeneity in the populations arising from study design ${ }^{66} 71{ }^{100}$ or a higher sensitivity of some biomarkers. ${ }^{94}$

\section{Quality of the evidence}

In our review, we used a comprehensive search strategy, assessed the quality of the included studies to allow us to focus on those of good quality, and used statistical techniques to analyse their results and combine and compare the findings. However, the included studies contain some methodological flaws in the design, conduct and reporting. Many are retrospective or use prospectively collected data for diagnosis purposes, and one of the most common limitations is the lack of reporting of the case-ascertainment strategy used in the study. These problems might lead to selection bias that could have affected the event rates and influence the variables included in the final model. The time of inception of the cohorts (ie, whether it was at diagnosis or on admission) was ill defined and patient selection may have been different across studies. Other common methodological issues are the lack of a justification for the sample size, the absence of a full definition of prognostic variables and the lack of standardisation of treatments which might have been dictated by the prognostic variables that were assessed (and, therefore, may have affected the likelihood of certain outcomes), the lack of blinded assessment of the outcomes (to the prognostic variables), and possible problems with data analysis related to the statistical methods for missing data.

\section{Potential biases in the review process}

Our search was performed up to July 2014. Publications after that date were not included in the review. We believe there are no biases in our searches within the search period and decisions on study eligibility. Although we used a highly sensitive search to minimise the influence of reporting biases related to duplicate and cumulative full publication, time lag, language, location and reference list citation, ${ }^{17}$ it is not possible to know how a study's findings might influence the researchers' decision to publish it; unlike in randomised trials where positive results for new treatments are more 
Table 6 Comparison of our study with existing systematic reviews and meta-analyses of clinical prediction rules

\begin{tabular}{|c|c|c|c|c|}
\hline Author, year & $\begin{array}{l}\text { Squizatto et al, } \\
2012^{146}\end{array}$ & Zhou et al, $2012^{148}$ & Kohn et al, $2015^{147}$ & Our study \\
\hline Study design & $\begin{array}{l}\text { Systematic review and } \\
\text { meta-analysis }\end{array}$ & Meta-analysis & $\begin{array}{l}\text { Systematic review and } \\
\text { meta-analysis }\end{array}$ & Systematic review and meta-analysis \\
\hline Years of search & Until August 2011 & Up to June 2012 & January 2000-March 2014 & Inception to July 2014 \\
\hline Databases for search & MEDLINE, EMBASE & MEDLINE, EMBASE & MEDLINE, EMBASE & MEDLINE, EMBASE, The Cochrane Library \\
\hline Language included & No language restriction & English & English & No language restriction \\
\hline Number of studies in review & 33 & 21 & 40 & 71 \\
\hline Type of studies included & Derivation, validation & Validation (external) & Derivation, validation & Derivation, validation, update and impact \\
\hline Number of models in review & 9 & 2 & 11 & $17(+7$ other types of models*) \\
\hline Type of models included & Clinical prediction rules & PESI and sPESI & Clinical prediction rules & All prognostic models \\
\hline Quality appraisal method used & $\begin{array}{l}\text { 3-point score for cohort } \\
\text { studies }\end{array}$ & Newcastle-Ottawa Scale & $\begin{array}{l}\text { QUADAS2 (diagnostic tool) } \\
\text { Domain approach }\end{array}$ & $\begin{array}{l}\text { Prognostic criteria } \\
\text { Domain approach }\end{array}$ \\
\hline $\begin{array}{l}\text { Analysis of stable PE patients } \\
\text { separately }\end{array}$ & No & No & No & Yes \\
\hline Outcome & $\begin{array}{l}\text { All-cause mortality, } \\
\text { adverse outcomes }\end{array}$ & $\begin{array}{l}\text { All-cause mortality, PE-related } \\
\text { mortality, adverse outcomes }\end{array}$ & All-cause mortality & $\begin{array}{l}\text { All-cause mortality, PE-related mortality, } \\
\text { adverse outcomes, VTE, major bleeding }\end{array}$ \\
\hline $\begin{array}{l}\text { Analysis of different outcomes } \\
\text { separately }\end{array}$ & Yes & Yes & Not applicable & Yes \\
\hline Time point & $\begin{array}{l}14 \text { days, } 30 \text { days, } \\
3 \text { months }\end{array}$ & Not reported & $\begin{array}{l}\text { In-hospital, } 7 \text { days, } 30 \text { days, } \\
3 \text { months }\end{array}$ & In-hospital/ 7 days, 30 days, 3 months \\
\hline $\begin{array}{l}\text { Analysis of different time } \\
\text { points separately }\end{array}$ & No & No & No & Yes \\
\hline Risk groups & Low-risk group & $\begin{array}{l}\text { Low-risk group vs high-risk } \\
\text { group }\end{array}$ & Low-risk group & Low-risk group and high-risk group \\
\hline $\begin{array}{l}\text { Number of cut-offs accounted } \\
\text { for }\end{array}$ & Single cut-off & Single cut-off & Single cut-off & $\begin{array}{l}\text { All available cut-offs (analysis along the risk } \\
\text { scale) }\end{array}$ \\
\hline $\begin{array}{l}\text { Summary estimate in } \\
\text { meta-analysis }\end{array}$ & $\begin{array}{l}\text { Event rate in patients at } \\
\text { low risk for all models } \\
\text { combined }\end{array}$ & Prognostic accuracy, ${ }^{\dagger}$ OR & Prognostic accuracy $^{\dagger}$ & $\begin{array}{l}\text { Prognostic accuracy, }{ }^{\dagger} \text { proportion of patients in } \\
\text { each risk group, event rates within each risk } \\
\text { group (absolute risk), population event rate }\end{array}$ \\
\hline $\begin{array}{l}\text { Overall summary estimate } \\
\text { from combined derivation and } \\
\text { validation studies }\end{array}$ & Yes & No & Yes & Yes \\
\hline $\begin{array}{l}\text { Summary estimate from } \\
\text { external validation studies }\end{array}$ & No & Yes & No & Yes \\
\hline Analysis of update studies & No & No & No & Yes \\
\hline Analysis of impact studies & No & No & No & Yes \\
\hline
\end{tabular}




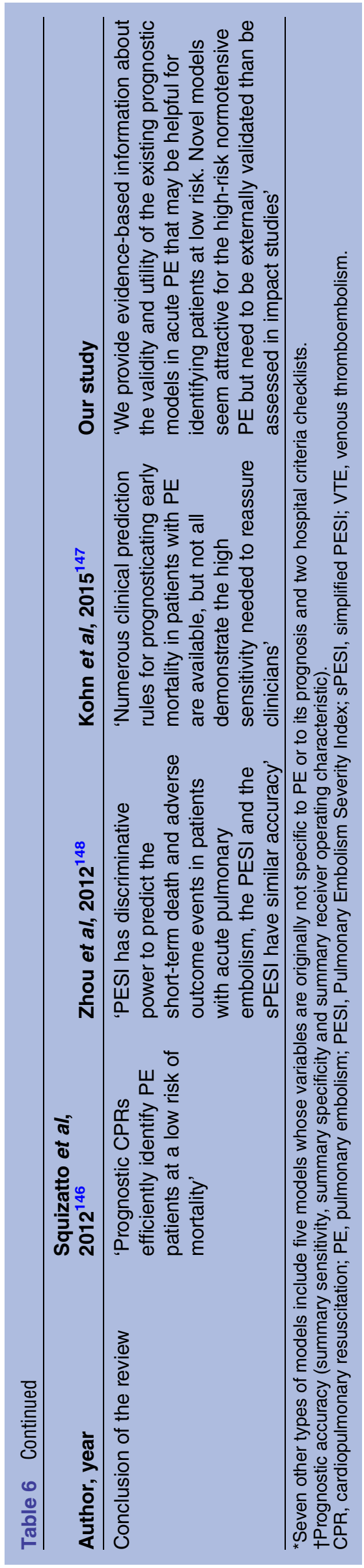

likely to lead to full publication. To assess publication bias for proportion and event rates, we applied statistical tests to detect funnel plot asymmetry, but we found little evidence of publication bias. According to Macaskill et $a l,{ }^{145}$ 'applying such tests in systematic review of diagnostic test accuracy is likely to result in publication bias being incorrectly indicated by the test far too often'.

Data extraction was performed by two reviewers. The second reviewer was not blinded to the data extracted. To ensure quality, data were rechecked by the first reviewer. We assessed study quality using a domain approach ${ }^{17}$ rather than a scale. This is more transparent to the reader, by showing how each study is performed in each aspect of conduct. As shown by Juni $e t a l{ }^{19}$ 'the use of summary scores to identify trials of high quality is problematic and relevant methodological aspects should be assessed individually and their influence on effect sizes explored'.

Our analyses were performed for distinct models, outcomes/time points, with subgroup and sensitivity analyses to deal with heterogeneity. We used multiple statistical techniques, which could introduce bias in the selection of results to present, but no discrepancies were found across the results and all analyses are available. We used absolute risk rather than relative risk because this is more appropriate for estimating the risks for individual patients.

\section{Comparison with other reviews}

This study was not limited to only clinical prediction rules and to our knowledge, it is the first broad systematic review and meta-analysis of prognostic models in patients with acute PE. There are two published systematic reviews on clinical prediction rules ${ }^{146} 147$ and a meta-analysis of PESI models, ${ }^{148}$ but, as discussed below, our systematic review has important differences to all of these, expands their scope considerably and provides more comprehensive and up-to-date data (table 6).

We believe the key strengths of our review are welldefined selection criteria, broad search strategy, and presentation of results of all available predictive models with full details on study characteristics, population and prognostic information and study quality. We used a domain approach and prognostic criteria for the assessment of study quality. Quantitative analyses are provided to answer each aspect of model development in accordance with the recommendations of recently published guidelines for prognostic model research, ${ }^{149}$ for different outcomes and time points in 'both stable and unstable' as well as in 'stable' $\mathrm{PE}$, and at various cut-offs, with the aim of improving management of patients with acute PE who are either at low risk or at high risk. For the analysis of performance, we provide a summary estimate of sensitivity and specificity and also a summary estimate of event rates ('absolute risk' ${ }^{\text {'149) }}$ within risk groups, which is more meaningful for clinicians and seems more appropriate for the study of prognosis. 


\section{CONCLUSIONS}

Our systematic review provides useful information on the prediction ability and the utility of existing prognostic models in acute PE that might help clinicians and researchers for the identification of patients at low risk of events for safe early discharge or outpatient management and those at high risk who may need closer monitoring or more aggressive therapy. It shows the potential for improving the selection of lower risk and higher risk groups in patients with normotensive PE with novel and updated models that integrate biomarkers (cTn, BNP, NT-proBNP, H-FABP), CT or TTE-RVD and US-detected DVT into existing models or with other clinical variables (systolic blood pressure, heart rate). These findings provide a good direction for future research in validation and impact studies.

Acknowledgements The authors wish to thank Nicola PEARCE-SMITH at the Department of Knowledge and Information Science, Oxford, UK, and Anne BRICE at James Lind Initiative, Oxford, UK for their helpful advice on search strategy.

Contributors $A E$ and $M C$ conceived the study. $A E, S M$, and MC designed the study. AE, MD-E and J-NP undertook the literature search and extracted data. $A E$ did data analysis. $A E, S M$ and $M C$ interpreted data. AE developed the first draft. $\mathrm{AE}$ and $\mathrm{MC}$ contributed to the writing of the manuscript. All authors provided critical comments and approved the final version. AE had full access to all the data in the study and had final responsibility for the decision to submit for publication. All researchers had access to all the data. AE as guarantor accepts full responsibility for the work and the conduct of the study. AE affirms that the manuscript is an honest, accurate, and transparent account of the study being reported; that no important aspects of the study have been omitted; and that any discrepancies from the study as planned have been explained.

Funding This research received no specific grant from any funding agency in the public, commercial or not-for-profit sectors.

Competing interests None declared.

Provenance and peer review Not commissioned; externally peer reviewed.

Data sharing statement No additional data are available.

Open Access This is an Open Access article distributed in accordance with the Creative Commons Attribution Non Commercial (CC BY-NC 4.0) license, which permits others to distribute, remix, adapt, build upon this work noncommercially, and license their derivative works on different terms, provided the original work is properly cited and the use is non-commercial. See: http:// creativecommons.org/licenses/by-nc/4.0/

\section{REFERENCES}

1. Torbicki A, Perrier A, Konstantinides S, et al. Guidelines on the diagnosis and management of acute pulmonary embolism: the Task Force for the Diagnosis and Management of Acute Pulmonary Embolism of the European Society of Cardiology (ESC). Eur Heart J 2008;29:2276-315.

2. Jaff MR, McMurtry MS, Archer SL, et al. Management of massive and submassive pulmonary embolism, iliofemoral deep vein thrombosis, and chronic thromboembolic pulmonary hypertension: a scientific statement from the American Heart Association. Circulation 2011;123:1788-830.

3. Konstantinides SV, Torbicki A, Agnelli G, et al. 2014 ESC guidelines on the diagnosis and management of acute pulmonary embolism. Eur Heart J 2014;35:3033-69, 69a-69k

4. Kearon C, Akl EA, Ornelas J, et al. Antithrombotic therapy for VTE disease: CHEST guideline and expert panel report. Chest 2016;149:315-52.
5. Becattini C, Vedovati MC, Agnelli G. Prognostic value of troponins in acute pulmonary embolism: a meta-analysis. Circulation 2007;116:427-33.

6. Klok FA, Mos IC, Huisman MV. Brain-type natriuretic peptide levels in the prediction of adverse outcome in patients with pulmonary embolism: a systematic review and meta-analysis. Am J Respir Crit Care Med 2008;178:425-30.

7. Sanchez O, Trinquart L, Colombet I, et al. Prognostic value of right ventricular dysfunction in patients with haemodynamically stable pulmonary embolism: a systematic review. Eur Heart $J$ 2008;29:1569-77.

8. Jimenez D, Uresandi F, Otero R, et al. Troponin-based risk stratification of patients with acute nonmassive pulmonary embolism: systematic review and metaanalysis. Chest 2009;136:974-82.

9. Lega JC, Lacasse Y, Lakhal L, et al. Natriuretic peptides and troponins in pulmonary embolism: a meta-analysis. Thorax 2009;64:869-75.

10. Altman DG. Prognostic models: a methodological framework and review of models for breast cancer. Cancer Invest 2009;27:235-43.

11. Mallett S, Royston $\mathrm{P}$, Dutton S, et al. Reporting methods in studies developing prognostic models in cancer: a review. BMC Med 2010;8:20.

12. Mallett $S$, Royston $P$, Waters $R$, et al. Reporting performance of prognostic models in cancer: a review. BMC Med 2010;8:21.

13. Williams C, Brunskill S, Altman D, et al. Cost-effectiveness of using prognostic information to select women with breast cancer for adjuvant systemic therapy. Health Technol Assess 2006;10:iii-iv, ix-xi, 1-204.

14. Altman DG. Systematic reviews of evaluations of prognostic variables. BMJ 2001;323:224-8.

15. Egger M, Juni $\mathrm{P}$, Bartlett $\mathrm{C}$, et al. How important are comprehensive literature searches and the assessment of trial quality in systematic reviews? Empirical study. Health Technol Assess 2003;7:1-76.

16. Hayden JA, Cote P, Bombardier C. Evaluation of the quality of prognosis studies in systematic reviews. Ann Intern Med 2006;144:427-37.

17. Higgins JPT, Green SE. Cochrane handbook for systematic reviews of interventions version 5.1.0 [updated March 2011]. The Cochrane Collaboration, 2011. http://www.cochrane-handbook.org

18. Schulz KF, Grimes DA, eds. Handbook of essential concepts in clinical research. Elsevier Ltd, 2006.

19. Juni $\mathrm{P}$, Witschi $\mathrm{A}$, Bloch $\mathrm{R}$, et al. The hazards of scoring the quality of clinical trials for meta-analysis. JAMA 1999;282:1054-60.

20. Harbord RM, Deeks JJ, Egger M, et al. A unification of models for meta-analysis of diagnostic accuracy studies. Biostatistics 2007;8:239-51.

21. Harbord RM, Whiting P. Metandi: meta-analysis of diagnostic accuracy using hierarchical logistic regression. Stata $J$ 2009;2:211-29.

22. Harbord R. Metandi: Stata module to perform meta-analysis of diagnostic accuracy. Bristol, UK: MRC Health Services Research Collaboration, University of Bristol, 2006.

23. Rabe-Hesketh S, Skrondal A, Pickles A. GLLAMM Manual. U.C. Berkeley Division of Biostatistics Working Paper Series. Working Paper 160, 2004. http://www.bepress.com/ucbbiostat/paper160

24. Moher D, Liberati A, Tetzlaff J, et al. Preferred reporting items for systematic reviews and meta-analyses: the PRISMA statement. PLoS Med 2009;6:e1000097.

25. Al Otair HA, Al-Boukai AA, Ibrahim GF, et al. Outcome of pulmonary embolism and clinico-radiological predictors of mortality: experience from a university hospital in Saudi Arabia. Ann Thorac Med 2014:9:18-22.

26. Almahameed A, Carman TL. Outpatient management of stable acute pulmonary embolism: proposed accelerated pathway for risk stratification. Am J Med 2007;120(Suppl 2):S18-25.

27. Bircan A, Karadeniz N, Ozden A, et al. A simple clinical model composed of ECG, shock index, and arterial blood gas analysis for predicting severe pulmonary embolism. Clin Appl Thromb Hemost 2011;17:188-96

28. Bledsoe J, Hamilton D, Bess E, et al. Treatment of low-risk pulmonary embolism patients in a chest pain unit. Crit Pathw Cardiol 2010;9:212-15.

29. Budaj-Fidecka A, Kurzyna M, Fija? kowska A, et al. In-hospital major bleeding predicts mortality in patients with pulmonary embolism: an analysis of ZATPOL Registry data. Int J Cardiol 2013;168:3543-9.

30. Cameron A, Ogilvie C, Teckchandani S, et al. Outpatient imaging for pulmonary embolism may only be suitable for a minority. Scott Med J 2012;57:14-17. 
31. Gallotta G, Palmieri V, Piedimonte V, et al. Increased troponin I predicts in-hospital occurrence of hemodynamic instability in patients with sub-massive or non-massive pulmonary embolism independent to clinical, echocardiographic and laboratory information. Int J Cardiol 2008;124:351-7.

32. Gul EE, Can I, Guler I, et al. Association of pulmonary artery obstruction index with elevated heart-type fatty acid binding protein and short-term mortality in patients with pulmonary embolism at intermediate risk. Diagn Interv Radiol 2012;18:531-6.

33. Lankeit M, Dellas C, Benz V, et al. The predictive value of heart-type fatty acid-binding protein is independent from symptom duration in normotensive patients with pulmonary embolism. Thromb Res 2013;132:543-7.

34. McCabe A, Hassan T, Doyle M, et al. Identification of patients with low-risk pulmonary embolism suitable for outpatient treatment using the pulmonary embolism severity index (PESI). Ir J Med Sci 2013;182:291-5.

35. Paiva L, Providencia R, Faustino A, et al. Manchester triage in acute pulmonary embolism: can it unmask the grand impersonator? Emerg Med J 2012;29:e6.

36. Palla A, Ribas C, Rossi G, et al. The clinical course of pulmonary embolism patients anticoagulated for 1 year: results of a prospective, observational, cohort study. J Thromb Haemost 2010;8:68-74.

37. Rydman R, Söderberg M, Larsen F, et al. d-Dimer and simplified pulmonary embolism severity index in relation to right ventricular function. Am J Emerg Med 2013;31:482-6.

38. Spirk D, Willenberg T, Aujesky D, et al. Use of biomarkers or echocardiography in pulmonary embolism: the Swiss Venous Thromboembolism Registry. QJM 2012;105:1163-9.

39. Taylor RA, Davis J, Liu R, et al. Point-of-care focused cardiac ultrasound for prediction of pulmonary embolism adverse outcomes. J Emerg Med 2013;45:392-9.

40. Tsai J, Abe K, Boulet SL, et al. Predictive accuracy of 29-comorbidity index for in-hospital deaths in US adult hospitalizations with a diagnosis of venous thromboembolism. PLOS ONE 2013;8:e70061.

41. George E, Kumamaru KK, Ghosh N, et al. Computed tomography and echocardiography in patients with acute pulmonary embolism: part 2: prognostic value. J Thorac Imaging 2014;29: W7-12.

42. Goldhaber SZ, Visani L, De Rosa M. Acute pulmonary embolism: clinical outcomes in the International Cooperative Pulmonary Embolism Registry (ICOPER). Lancet 1999;353:1386-9.

43. Kanbay A, Kokturk N, Kaya MG, et al. Electrocardiography and Wells scoring in predicting the anatomic severity of pulmonary embolism. Respir Med 2007;101:1171-6.

44. Kasper W, Konstantinides S, Geibel A, et al. Management strategies and determinants of outcome in acute major pulmonary embolism: results of a multicenter registry. J Am Coll Cardiol 1997;30:1165-71.

45. Konstantinides S, Geibel A, Olschewski M, et al. Association between thrombolytic treatment and the prognosis of hemodynamically stable patients with major pulmonary embolism: results of a multicenter registry. Circulation 1997;96:882-8.

46. Kucher N, Wallmann D, Carone A, et al. Incremental prognostic value of troponin I and echocardiography in patients with acute pulmonary embolism. Eur Heart J 2003;24:1651-6.

47. Rodríguez-Cerrillo M, Alvarez-Arcaya A, Fernández-Díaz E, et al. A prospective study of the management of non-massive pulmonary embolism in the home. Eur J Intern Med 2009;20: 598-600.

48. Sen HS, Abakay O, Tanrikulu AC, et al. Is a complete blood cell count useful in determining the prognosis of pulmonary embolism? Wien Klin Wochenschr 2014;126:347-54.

49. Hariharan P, Takayesu JK, Kabrhel C. Erratum to: Association between the Pulmonary Embolism Severity Index (PESI) and short-term clinical deterioration (Thromb Haemost 2011; 105: 706711). Thromb Haemost 2012;107:599-9.

50. Aujesky D, Roy PM, Le Manach CP, et al. Validation of a model to predict adverse outcomes in patients with pulmonary embolism. Eur Heart J 2006;27:476-81.

51. Zondag W, Hiddinga BI, Crobach MJT, et al. Hestia criteria can discriminate high- from low-risk patients with pulmonary embolism. Eur Respir J 2013;41:588-92.

52. Zondag W, Mos ICM, Creemers-Schild D, et al. Outpatient treatment in patients with acute pulmonary embolism: the Hestia Study. J Thromb Haemost 2011;9:1500-7.

53. Barra S, Paiva L, Providencia R, et al. LR-PED rule: low risk pulmonary embolism decision rule-a new decision score for low risk pulmonary embolism. Thromb Res 2012;130:327-33.
54. Moores L, Zamarro C, Gómez V, et al. Changes in PESI scores predict mortality in intermediate-risk patients with acute pulmonary embolism. Eur Respir J 2013;41:354-9.

55. Otero R, Trujillo-Santos J, Cayuela A, et al. Haemodynamically unstable pulmonary embolism in the RIETE Registry: systolic blood pressure or shock index? Eur Respir J 2007;30:1111-16.

56. Stuck AK, Stone RA, Pugh N, et al. Comparison of the Pulmonary Embolism Severity Index to a simplified version: classification and clinical outcomes. Thromb Res 2014;133:515-16.

57. Dunn AS. ACP Journal Club. The simplified Pulmonary Embolism Severity Index and high-sensitivity troponin T predicted prognosis in PE. Ann Intern Med 2012;156:JC4-12.

58. Gould MK. A clinical prediction model was sensitive but not specific for predicting mortality in pulmonary embolism. ACP J Club 2006;145:53.

59. O'Flaherty M, Gandara E. A simple prediction rule identified patients with pulmonary embolism at low risk of short term death. Evid Based Med 2006;11:121.

60. Golpe R, Perez-de-Llano LA, Castro-Anon O. Prognostic value of the Charlson comorbidity index in pulmonary embolism. Respiration 2013;85:438

61. Ahmad N, Srinivasan K, Moudgil H. Risk stratification in pulmonary embolism: an algorithmic tool approach. Thorax 2011;66:1098-9.

62. Chow V, $\mathrm{Ng} \mathrm{AC}$, Chung $\mathrm{T}$, et al. Right atrial to left atrial area ratio on early echocardiography predicts long-term survival after acute pulmonary embolism. Cardiovasc Ultrasound 2013;11:17.

63. Fraga $M$, Taffe $\mathrm{P}$, Mean $\mathrm{M}$, et al. The inter-rater reliability of the Pulmonary Embolism Severity Index. Thromb Haemost 2010;104:1258-62.

64. Sequeira JF, Duarte PC, Madruga IM, et al. [Pulmonary embolism--mortality risk]. Rev Port Cardiol 1992;11:749-57.

65. Agterof MJ, Schutgens RE, Moumli N, et al. A prognostic model for short term adverse events in normotensive patients with pulmonary embolism. Am J Hematol 2011;86:646-9.

66. Agterof MJ, Schutgens REG, Snijder RJ, et al. Out of hospital treatment of acute pulmonary embolism in patients with a low NT-proBNP level. J Thromb Haemost 2010;8:1235-41.

67. Agterof MJ, Van Bladel ER, Schutgens REG, et al. Risk stratification of patients with pulmonary embolism based on pulse rate and D-dimer concentration. Thromb Haemost 2009;102:683-7.

68. Aujesky D, Obrosky DS, Stone RA, et al. Derivation and validation of a prognostic model for pulmonary embolism. Am J Respir Crit Care Med 2005;172:1041-6.

69. Aujesky D, Obrosky DS, Stone RA, et al. A prediction rule to identify low-risk patients with pulmonary embolism. Arch Intern Med 2006;166:169-75.

70. Aujesky D, Perrier A, Roy PM, et al. Validation of a clinical prognostic model to identify low-risk patients with pulmonary embolism. J Intern Med 2007;261:597-604.

71. Aujesky D, Roy PM, Verschuren F, et al. Outpatient versus inpatient treatment for patients with acute pulmonary embolism: an international, open-label, randomised, non-inferiority trial. Lancet 2011:378:41-8.

72. Becattini C, Casazza F, Forgione C, et al. Acute pulmonary embolism: external validation of an integrated risk stratification model. Chest 2013;144:1539-45.

73. Bertoletti L, Le Gal G, Aujesky D, et al. Prognostic value of the Geneva prediction rule in patients with pulmonary embolism. Thromb Res 2013;132:32-6.

74. Bova C, Pesavento R, Marchiori A, et al. Risk stratification and outcomes in hemodynamically stable patients with acute pulmonary embolism: a prospective, multicentre, cohort study with three months of follow-up. J Thromb Haemost 2009;7:938-44.

75. Chan CM, Woods C, Shorr AF. The validation and reproducibility of the pulmonary embolism severity index. $J$ Thromb Haemost 2010;8:1509-14.

76. Chan CM, Woods CJ, Shorr AF. Comparing the pulmonary embolism severity index and the prognosis in pulmonary embolism scores as risk stratification tools. J Hosp Med 2012;7:22-7.

77. Choi KJ, Cha SI, Shin KM, et al. Prognostic implications of computed tomographic right ventricular dilation in patients with acute pulmonary embolism. Thromb Res 2014;133:182-6.

78. Choi WH, Kwon SU, Jwa YJ, et al. The pulmonary embolism severity index in predicting the prognosis of patients with pulmonary embolism. Korean J Intern Med 2009;24:123-7.

79. Davies CWH, Wimperis J, Green ES, et al. Early discharge of patients with pulmonary embolism: a two-phase observational study. Eur Respir J 2007;30:708-14.

80. Dellas C, Tschepe M, Seeber V, et al. A novel H-FABP assay and a fast prognostic score for risk assessment of normotensive pulmonary embolism. Thromb Haemost 2014;111:996-1003. 
81. Donze J, Le Gal G, Fine MJ, et al. Prospective validation of the Pulmonary Embolism Severity Index: a clinical prognostic model for pulmonary embolism. Thromb Haemost 2008;100:943-8.

82. Erkens PMG, Gandara E, Wells PS, et al. Does the Pulmonary Embolism Severity Index accurately identify low risk patients eligible for outpatient treatment? Thromb Res 2012;129:710-14.

83. Ferrer M, Morillo R, Elias T, et al. Validation of two clinical prognostic models in patients with acute symptomatic pulmonary embolism. Arch Bronconeumol 2013;49:427-31.

84. Hariharan P, Takayesu JK, Kabrhel C. Association between the pulmonary embolism severity index (PESI) and short-term clinical deterioration. Thromb Haemost 2011;105:706-11.

85. Jimenez D, Aujesky D, Moores L, et al. Simplification of the pulmonary embolism severity index for prognostication in patients with acute symptomatic pulmonary embolism. Arch Intern Med 2010;170:1383-9.

86. Jimenez D, Aujesky D, Moores L, et al. Combinations of prognostic tools for identification of high-risk normotensive patients with acute symptomatic pulmonary embolism. Thorax 2011;66:75-81.

87. Jiménez $\mathrm{D}$, Kopecna $\mathrm{D}$, Tapson $\mathrm{V}$, et al. Derivation and validation of multimarker prognostication for normotensive patients with acute symptomatic pulmonary embolism. Am J Respir Crit Care Med 2014;189:718-26.

88. Jimenez D, Yusen RD, Otero R, et al. Prognostic models for selecting patients with acute pulmonary embolism for initial outpatient therapy. Chest 2007:132:24-30.

89. Jo JY, Lee MY, Lee JW, et al. Leukocytes and systemic inflammatory response syndrome as prognostic factors in pulmonary embolism patients. BMC Pulm Med 2013;13:74

90. Kostrubiec M, Pruszczyk P, Bochowicz A, et al. Biomarker-based risk assessment model in acute pulmonary embolism. Eur Heart $J$ 2005;26:2166-72

91. Kukla P, Bryniarski L, Dlugopolski R, et al. Acute pulmonary embolism registry in the Malopolska region-clinical course. Kardiol Pol 2009;67:735-41.

92. Lankeit M, Friesen D, Schafer K, et al. A simple score for rapid risk assessment of non-high-risk pulmonary embolism. Clin 2013;102:73-80.

93. Lankeit M, Gomez V, Wagner C, et al. A strategy combining imaging and laboratory biomarkers in comparison with a simplified clinical score for risk stratification of patients with acute pulmonary embolism. Chest 2012;141:916-22.

94. Lankeit M, Jimenez D, Kostrubiec M, et al. Predictive value of the high-sensitivity troponin T assay and the simplified pulmonary embolism severity index in hemodynamically stable patients with acute pulmonary embolism: a prospective validation study. Circulation 2011:124:2716-24.

95. Lankeit M, Jiménez $\mathrm{D}$, Kostrubiec $\mathrm{M}$, et al. Validation of $\mathrm{N}$-terminal pro-brain natriuretic peptide cut-off values for risk stratification of pulmonary embolism. Eur Respir J 2014;43:1669-77.

96. Moores L, Aujesky D, Jimenez D, et al. Pulmonary Embolism Severity Index and troponin testing for the selection of low-risk patients with acute symptomatic pulmonary embolism. J Thromb Haemost 2010;8:517-22.

97. Nendaz MR, Bandelier P, Aujesky D, et al. Validation of a risk score identifying patients with acute pulmonary embolism, who are at low risk of clinical adverse outcome. Thromb Haemost 2004;91:1232-6.

98. $\mathrm{Ng} \mathrm{AC}$, Chow V, Yong AS, et al. Prognostic impact of the Charlson comorbidity index on mortality following acute pulmonary embolism. Respiration 2013;85:408-16.

99. Nordenholz K, Ryan J, Atwood B, et al. Pulmonary embolism risk stratification: pulse oximetry and pulmonary embolism severity index. J Emerg Med 2011;40:95-102.

100. Otero $R$, Uresandi F, Jimenez D, et al. Home treatment in pulmonary embolism. Thromb Res 2010;126:e1-5.

101. Ozsu S, Abul Y, Orem A, et al. Predictive value of troponins and simplified pulmonary embolism severity index in patients with normotensive pulmonary embolism. Multidiscip Respir Med 2013;8:34.

102. Ozsu S, Ozlu T, Şentürk A, et al. Combination and comparison of two models in prognosis of pulmonary embolism: results from Turkey Pulmonary Embolism Group (TUPEG) study. Thromb Res 2014;133:1006-10.

103. Paiva LV, Providencia RC, Barra SN, et al. Cardiovascular risk assessment of pulmonary embolism with the GRACE risk score. Am J Cardiol 2013;111:425-31.

104. Palmieri V, Gallotta G, Rendina D, et al. Troponin I and right ventricular dysfunction for risk assessment in patients with nonmassive pulmonary embolism in the Emergency Department in combination with clinically based risk score. Intern Emerg Med 2008;3:131-8.
105. Papaioannou Al, Kastanis A, Malli F, et al. Predicting short-term mortality in patients with pulmonary embolism: a simple model. Am J Med Sci 2013;345:462-9.

106. Righini M, Roy PM, Meyer G, et al. The Simplified Pulmonary Embolism Severity Index (PESI): validation of a clinical prognostic model for pulmonary embolism. $J$ Thromb Haemost 2011:9:2115-17.

107. Roca IC, Aursulesei V, Roca M, et al. [Comparative evaluation of prognostic scores in pulmonary embolism]. Rev Med Chir Soc Med Nat lasi 2012;116:69-74.

108. Sam A, Sanchez D, Gomez V, et al. The shock index and the simplified PESI for identification of low-risk patients with acute pulmonary embolism. Eur Respir J 2011;37:762-6.

109. Sanchez D, De Miguel J, Sam A, et al. The effects of cause of death classification on prognostic assessment of patients with pulmonary embolism. J Thromb Haemost 2011;9:2201-7.

110. Sanchez O, Trinquart $L$, Caille V, et al. Prognostic factors for pulmonary embolism: the PREP study, a prospective multicenter cohort study. Am J Respir Crit Care Med 2010;181:168-73.

111. Sanchez O, Trinquart L, Planquette B, et al. Echocardiography and pulmonary embolism severity index have independent prognostic roles in pulmonary embolism. Eur Respir J 2013;42:681-8.

112. Singanayagam A, Chalmers JD, Scally C, et al. Right ventricular dilation on CT pulmonary angiogram independently predicts mortality in pulmonary embolism. Respir Med 2010;104:1057-62.

113. Singanayagam A, Scally C, Al-Khairalla MZ, et al. Are biomarkers additive to pulmonary embolism severity index for severity assessment in normotensive patients with acute pulmonary embolism? QJM 2011;104:125-31.

114. Soares TH, de Bastos M, de Carvalho BV, et al. Prognostic value of computed tomographic pulmonary angiography and the pulmonary embolism severity index in patients with acute pulmonary embolism. Blood Coagul Fibrinolysis 2013;24: 64-70.

115. Spirk D, Aujesky D, Husmann M, et al. Cardiac troponin testing and the simplified pulmonary embolism severity index the Swiss venous thromboembolism registry (SWIVTER). Thromb Haemost 2011;106:978-84

116. Subramaniam RM, Mandrekar J, Blair D, et al. The Geneva prognostic score and mortality in patients diagnosed with pulmonary embolism by CT pulmonary angiogram. $J$ Med Imaging Radiat Oncol 2009;53:361-5.

117. Toosi MS, Merlino JD, Leeper KV. Prognostic value of the shock index along with transthoracic echocardiography in risk stratification of Patients With Acute Pulmonary Embolism. Am J Cardiol 2008;101:700-5.

118. Uresandi F, Otero R, Cayuela A, et al. A clinical prediction rule for identifying short-term risk of adverse events in patients with pulmonary thromboembolism. [Spanish]. Arch Bronconeumol 2007:43:617-22.

119. Vanni S, Nazerian P, Pepe G, et al. Comparison of two prognostic models for acute pulmonary embolism: clinical vs. right ventricular dysfunction-guided approach. J Thromb Haemost 2011;9:1916-23.

120. Venetz $\mathrm{C}$, Jimenez $\mathrm{D}$, Mean $\mathrm{M}$, et al. A comparison of the original and simplified pulmonary embolism severity index. Thromb Haemost 2011;106:423-8.

121. Volschan A, Albuquerque D, Tura BR, et al. Predictors of hospital mortality in hemodynamically stable patients with pulmonary embolism. [Portuguese, Spanish, English]. Arq Bras Cardiol 2009;93:135-40.

122. Wicki J, Perrier A, Perneger TV, et al. Predicting adverse outcome in patients with acute pulmonary embolism: q risk score. Thromb Haemost 2000;84:548-52.

123. Yamaki T, Nozaki M, Sakurai $\mathrm{H}$, et al. Presence of lower limb deep vein thrombosis and prognosis in patients with symptomatic pulmonary embolism: preliminary report. Eur J Vasc Endovasc Surg 2009;37:225-31.

124. Zhu L, Wang C, Yang YH, et al. [Prognostic value of right ventricular dysfunction and derivation of a prognostic model for patients with acute pulmonary thromboembolism]. Zhonghua Liu Xing Bing Xue Za Zhi 2009;30:184-8.

125. Zondag W, den Exter PL, Crobach MJT, et al. Comparison of two methods for selection of out of hospital treatment in patients with acute pulmonary embolism. Thromb Haemost 2013;109:47-52.

126. Zondag W, Vingerhoets LMA, Durian MF, et al. Hestia criteria can safely select patients with pulmonary embolism for outpatient treatment irrespective of right ventricular function. $J$ Thromb Haemost 2013;11:686-92.

127. Barra SNC, Paiva LV, Providência R, et al. Atrial fibrillation in acute pulmonary embolism: prognostic considerations. Emerg Med $\mathrm{J}$ 2014;31:308-12. 
128. Beer JH, Burger M, Gretener S, et al. Outpatient treatment of pulmonary embolism is feasible and safe in a substantial proportion of patients. J Thromb Haemost 2003;1:186-7.

129. Huang CM, Lin YC, Lin YJ, et al. Risk stratification and clinical outcomes in patients with acute pulmonary embolism. Clin Biochem 2011;44:1110-15.

130. Jakobsson C, Jimenez D, Gomez V, et al. Validation of a clinical algorithm to identify low-risk patients with pulmonary embolism. J Thromb Haemost 2010;8:1242-7.

131. Labyk A, Ciurzynski M, Jankowski K, et al. Acute pulmonary embolism: analysis of consecutive 353 patients hospitalised in a single centre. A 3-year experience. Kardiologia polska 2012;70:15-22.

132. Meyer G, Vicaut E, Danays T, et al. Fibrinolysis for patients with intermediate-risk pulmonary embolism. N Engl J Med 2014;370:1402-11.

133. Stamm JA, Long JL, Kirchner HL, et al. Risk Stratification in acute pulmonary embolism: frequency and impact on treatment decisions and outcomes. South Med J 2014;107:72-8.

134. Vuilleumier N, Le Gal G, Cornily JC, et al. Is N-terminal pro-brain natriuretic peptide superior to clinical scores for risk stratification in non-massive pulmonary embolism? J Thromb Haemost 2010;8:1433-5.

135. Bova C, Sanchez O, Prandoni $P$, et al. Identification of intermediate-risk patients with acute symptomatic pulmonary embolism. Eur Respir J 2014;44:694-703.

136. Perrier A, Howarth N, Didier D, et al. Performance of helical computed tomography in unselected outpatients with suspected pulmonary embolism. Ann Intern Med 2001;135:88-97.

137. Perrier A, Roy PM, Aujesky D, et al. Diagnosing pulmonary embolism in outpatients with clinical assessment, D-dimer measurement, venous ultrasound, and helical computed tomography: a multicenter management study. Am J Med 2004;116:291-9.

138. Perrier A, Roy PM, Sanchez O, et al. Multidetector-row computed tomography in suspected pulmonary embolism. $N$ Engl J Med 2005;352:1760-8.

139. Righini M, Le Gal G, Aujesky D, et al. Diagnosis of pulmonary embolism by multidetector CT alone or combined with venous ultrasonography of the leg: a randomised non-inferiority trial. Lancet 2008;371:1343-52.

140. Roy PM, Meyer G, Vielle B, et al. Appropriateness of diagnostic management and outcomes of suspected pulmonary embolism. Ann Intern Med 2006;144:157-64.

141. Vuilleumier N, Le Gal G, Verschuren F, et al. Cardiac biomarkers for risk stratification in non-massive pulmonary embolism: a multicenter prospective study. J Thromb Haemost 2009;7:391-8.

142. Pencina MJ, D'Agostino RB Sr, D'Agostino RB Jr, et al. Evaluating the added predictive ability of a new marker: from area under the ROC curve to reclassification and beyond. Stat Med 2008;27:157-72; discussion 207-12.

143. McGinn TG, Guyatt GH, Wyer PC, et al. Users' guides to the medical literature: XXII: how to use articles about clinical decision rules. Evidence-Based Medicine Working Group. JAMA 2000;284:79-84

144. Vinson DR, Zehtabchi S, Yealy DM. Can selected patients with newly diagnosed pulmonary embolism be safely treated without hospitalization? A systematic review. Ann Emerg Med 2012;60:651-62.e4.

145. Macaskill P, Gatsonis C, Deeks JJ, et al. Chapter 10: analysing and presenting results. In: Deeks JJ, Bossuyt PM, Gatsonis C, eds. Cochrane handbook for systematic reviews of diagnostic test accuracy version 1.0. The Cochrane Collaboration, 2010. http:// srdta.cochrane.org/

146. Squizzato A, Donadini MP, Galli L, et al. Prognostic clinical prediction rules to identify a low-risk pulmonary embolism: a systematic review and meta-analysis. J Thromb Haemost 2012;10:1276-90.

147. Kohn CG, Mearns ES, Parker MW, et al. Prognostic accuracy of clinical prediction rules for early post-pulmonary embolism all-cause mortality: a bivariate meta-analysis. Chest 2015;147:1043-62.

148. Zhou XY, Ben SQ, Chen HL, et al. The prognostic value of pulmonary embolism severity index in acute pulmonary embolism: a meta-analysis. Respir Res 2012;13:111.

149. Steyerberg EW, Moons KG, van der Windt DA, et al. Prognosis Research Strategy (PROGRESS) 3: prognostic model research. PLoS Med 2013:10:e1001381. 